\title{
Corporate Governance and Innovation: Theory and Evidence
}

\author{
Haresh Sapra, Ajay Subramanian, and Krishnamurthy V. \\ Subramanian*
}

\begin{abstract}
We develop a theory to show how external and internal corporate governance mechanisms affect innovation. We predict a U-shaped relation between innovation and external takeover pressure, which arises from the interaction between expected takeover premia and private benefits of control. Using ex ante and ex post innovation measures, we find strong empirical support for the predicted relation. We exploit the variation in takeover pressure created by the passage of antitakeover laws across different states. Innovation is fostered either by an unhindered market for corporate control or by antitakeover laws that are severe enough to effectively deter takeovers.
\end{abstract}

\section{Introduction}

A growing body of evidence shows that laws and institutions that influence corporate governance correlate with economic growth (e.g., La Porta, Lopez-deSilanes, Shleifer, and Vishny (2000)). Another strand of the literature demonstrates that economic growth results from firm-level innovation (e.g., Aghion and

*Sapra, hsapra@chicagobooth.edu, Booth School of Business, University of Chicago, 5807 S Woodlawn Ave, Chicago, IL 60637; Subramanian, asubramanian@gsu.edu, Robinson College of Business, Georgia State University, 35 Broad Street, Atlanta, GA 30303; and Subramanian, krishnamurthy_subramanian@isb.edu, Indian School of Business, Gachibowli, Hyderabad, Telangana 500032, India. We thank an anonymous reviewer and Jarrad Harford (the editor) for valuable comments. We also thank Viral Acharya, Phil Berger, Riccardo Calcagno, Enrico Perotti, Josh Rauh, Sriram Venkataraman, and conference and seminar participants at the 2009 NBER Law and Economics Spring meetings, the 2008 NBER Summer Institute on Corporate Finance, the 2008 RICAFE2 Conference on Entrepreneurship and Innovation, the 2009 Conference on Empirical Legal Studies, the 2009 Symposium on Financial Intermediation Markets, the 2009 Conference on National Institute of Security Markets, the 2007 All-Georgia Finance Conference, the 2009 Carnegie-Mellon University Theory Conference, the 2009 Emory University Finance seminar, the 2009 Emory University-Georgia Institute of Technology joint seminar series on Entrepreneurship, Innovation, and Public Policy, Georgia State University, Temple University, the University of Chicago, the University of Colorado, the University of Minnesota, the University of Maryland, and the 2010 University of Texas at Austin Accounting and Corporate Governance conference for valuable comments. We thank Ningzhong Li for excellent research assistance. We thank the University of Chicago Booth School of Business, the Georgia State University Robinson College of Business, the Emory University Goizueta Business School, Indian School of Business, and the Kauffman Foundation for financial support. The usual disclaimers apply. 
Howitt (2006)). From both theoretical and empirical standpoints, however, our knowledge of how laws and institutions shape the innovation choices of firms at the micro level through corporate governance is still relatively nascent. Innovation by firm managers is affected by the incentives provided by internal as well as external governance mechanisms such as the market for corporate control. Antitakeover laws potentially influence managers' implicit incentives through the market for corporate control.

We develop a theory to show how external mechanisms for corporate governance, such as antitakeover laws, interact with a firm's internal mechanisms, such as managerial incentive contracts, to affect firm-level innovation. Our theory generates the novel testable implication that innovation varies nonmonotonically in a U-shaped manner with the takeover pressure faced by firms. The U-shaped relation arises through the interaction between expected takeover premia and private benefits of control, both of which vary with takeover pressure. In contrast, previous theories predict a monotonic, either increasing or decreasing, relation. We demonstrate strong empirical support for the predicted U-shaped relation by exploiting the staggered passages of antitakeover laws by U.S. states as a source of cross-sectional and time-series variation in takeover pressure, and using ex ante as well as ex post proxies for innovation. We conduct several tests to account for the effects of unobserved determinants of innovation that may accompany the antitakeover law passages. In particular, we exploit hand-collected data on patents filed by the specific subsidiaries/divisions of a firm that are located outside the state of incorporation of the parent firm to isolate the pure effects of antitakeover law passages on innovation. In particular, our finding of a nonmonotonic relation between innovation and takeover pressure qualifies the results of prior empirical studies that test for a monotonic relation. Broadly, our study suggests that innovation is fostered either by practically nonexistent antitakeover laws that permit an unhindered market for corporate control or by antitakeover laws that are severe enough to effectively deter takeovers.

To motivate our model, consider the following example. Suppose the manager of a pharmaceutical company could invest in one of the following projects: i) inventing a new drug or ii) manufacturing a generic substitute. Launching a generic substitute involves uncertainties due to customer demand and competition. In contrast, inventing a new drug entails additional uncertainties associated with the process of "exploration." In particular, a significant portion of the uncertainty associated with a generic substitute lies in the marketing stage, whereas a relatively greater proportion of the uncertainty associated with a new drug lies in the exploration stage.

We formalize the essence of the above example in a two-period model in which the manager of a firm chooses to invest in one of two projects: a more innovative project or a less innovative project. The projects' payoffs are uncertain and occur at the end of the second period. There is imperfect, but symmetric, information about the true expected payoffs or qualities of the projects. The manager's project choice is observable. At the end of the first period, agents observe a public signal that partially resolves the uncertainty associated with the project's terminal payoff. Based on this signal, all agents update their prior assessments of the project's quality. The more innovative project has a higher mean quality 
than the less innovative project. Furthermore, because innovation entails significantly more uncertainty with respect to exploration, the posterior assessments of the quality of the more innovative project are more variable; that is, the posterior distribution has heavier tails. Finally, the posterior distributions of the two projects satisfy a monotone likelihood ratio property (MLRP): A change in agents' mean assessment of project quality based on the interim signal is more likely to be generated by the more innovative project as the magnitude of the change increases.

At the end of the first period, the firm could be acquired by another firm ("raider") through a tender offer. There is imperfect, but symmetric information about the value generated by the raider. The severity of antitakeover laws influences both the takeover pressure the firm faces and the firm's bargaining power when it negotiates with the raider (Bebchuk and Cohen (2003)). The bargaining power is reflected in the minimum takeover premium the firm must be guaranteed by the raider. The raider could either create or destroy firm value. In equilibrium, however, the firm is taken over only if the raider adds value based on the information available to agents in the market. Furthermore, the firm is taken over only if the intermediate signal is sufficiently bad so that the posterior assessment of the quality of the firm's project is below a certain threshold. The threshold level below which the firm could be taken over falls with the severity of antitakeover laws so that the likelihood of a takeover decreases with the severity of antitakeover laws. Furthermore, because posterior quality assessments are more variable for the more innovative project, the firm undertaking the more innovative project is more likely to be taken over.

The prediction that highly innovative firms could be taken over if intermediate signals of their project outcomes are poor is consistent with empirical evidence (Desyllas and Hughes (2009)). Our focus on "disciplinary" takeovers in the basic model in which underperforming firms are taken over is consistent with Jensen (1988), Scharfstein (1988), and Stein (1988). Nevertheless, in Appendix B, we show that our predictions are robust to a setting that also accommodates "synergistic" takeovers in which firms with high intermediate signals could also be taken over because of potential synergies with an acquiring firm.

We capture two frictions in our environment. First, even though the manager's project choice is observable, it is nonverifiable and, therefore, noncontractible. Second, as in Bebchuk and Jolls (1999), the manager derives pecuniary private control benefits that are observable but noncontractible. If the firm is taken over, the manager cedes her control benefits to the raider. The project's payoff net of the manager's control benefits and the payoff conditional on the firm being taken over are contractible. The shareholders can influence the manager's project choice through a compensation contract contingent on the project's contractible payoffs.

We show that the manager's optimal compensation contract can be implemented through a restricted equity stake in the firm along with a payment that resembles a golden parachute in the event of a takeover. The golden parachute aligns the interests of the manager and shareholders by effectively compensating the manager for her loss of control benefits in the event of a takeover. The manager's optimal project choice maximizes the firm's expected unconditional 
payoff (expected payoff in the absence of a takeover) plus the expected takeover premium less the expected loss of private benefits in the event of a takeover.

In choosing the degree of innovation, the manager faces the following tradeoff. Choosing the more innovative project increases the firm's likelihood of being taken over and, therefore, increases the manager's expected loss of control benefits. However, choosing the more innovative project results in a larger expected takeover premium because the more innovative project has a higher likelihood of being taken over, and the posterior assessments of its quality are more variable. The manager trades off the positive effect of greater innovation on the expected unconditional payoff and the expected takeover premium against its negative effect on the expected loss of control benefits. The trade-off is influenced by the interaction between the level of private benefits the manager is able to extract and the takeover pressure the firm faces.

The predicted U-shaped relation between the degree of innovation and external takeover pressure arises as follows. When the takeover pressure is very low, the low likelihood of a takeover implies that the expected takeover premium and the expected loss of control benefits are insignificant for both projects. Therefore, the manager chooses greater innovation because it has a higher expected unconditional payoff. When takeover pressure is very high, the expected takeover premium and the expected loss in control benefits are both high. At high levels of takeover pressure, the takeover probabilities are similar for both projects so that the expected loss of control benefits are also similar. The expected takeover premium, however, is higher for the more innovative project because it depends not only on the probability of a takeover but also on the size of the takeover premium conditional on a takeover. Consequently, it is again optimal to choose greater innovation when takeover pressure is high. For moderate levels of takeover pressure, the effect of the higher loss of control benefits associated with greater innovation dominates. It is therefore optimal for the manager to choose lower innovation to reduce the likelihood of losing her control benefits.

We empirically test the predicted U-shaped relation between the degree of innovation and the external takeover pressure faced by a firm. We employ both ex ante and ex post measures of the degree of innovation. We use research and development (R\&D) intensity as our ex ante measure, and patents and citations to these patents as our ex post measures. To identify the effects of external takeover pressure on innovation, we exploit the substantial cross-sectional and time-series variation in takeover pressure created by the staggered passage of all antitakeover laws in different states (see Figure 1 later in this article).

Although the previous literature has focused on the effects of business combination laws, all the antitakeover laws are likely to matter in the context of innovation. For example, Field and Karpoff (2002) find that the percentages of firms covered by the control share acquisition, fair price, business combination, and poison pill statutes at the initial public offering (IPO) stage equal 19.7, 10.7, 79.8, and 18.3, respectively. Because IPO firms are younger than the typical public firm and innovation is more likely to be undertaken by young firms (Kortum and Lerner (1999)), focusing solely on the effects of business combination laws may be unwarranted in the innovation context. 
We employ ordinary least squares (OLS) regressions using the logarithm of 1 plus patents and 1 plus citations, respectively. Hall, Jaffe, and Trajtenberg (2001) recommend using either OLS with the logarithmic transformation or countbased models (such as negative binomial or Poisson). Although our results are similar using the count-based models, the identifying assumptions required in such models are restrictive in practice (Wooldridge (2002), p. 675). Furthermore, because we test for the predicted U-shaped relation, interpreting the marginal effect of the coefficient of the quadratic term is problematic in nonlinear models (see Ai and Norton (2003), Lel and Miller (2008)).

First, we test our hypotheses using panel regressions with firm and year fixed effects, which enable us to estimate the effects as a difference-in-difference in a multiple-treatment group, multiple-period setting (Imbens and Wooldridge (2009)). Using quadratic and piecewise linear specifications as well as firm- and industry-level control variables, we show that innovation varies in a U-shaped manner with the antitakeover index as predicted by the theory. The economic magnitudes of the predicted effects are significant as well. When the value of the antitakeover index before a law passage is 0 (4), as it was in Delaware (Indiana), a 1-point increase in the value of the index decreases (increases) annual R\&D/ Sales by $4.0 \%(12.0 \%)$ of the mean R\&D/Sales and annual patents and citations by $8.7 \%$ and $14.9 \%(11.5 \%$ and $19.1 \%)$, respectively. Apart from the input to innovation (i.e., R\&D investment) and the outputs of innovation (i.e., patents and citations), changes in takeover pressure may affect the productivity/efficiency of innovation as well. We test and find a similar U-shaped relation using the number of patents per dollar of $R \& D$ and the number of citations per dollar of $R \& D$; that is, the effects of takeover pressure on innovation manifest at the intrinsic and extrinsic margins.

The inferences from our initial set of tests could be distorted by the fact that there might be unobserved factors leading to antitakeover law passages that are also correlated with firm-level innovation. We conduct several additional tests to mitigate these concerns. First, to account for unobserved state-level factors accompanying antitakeover law passages, we include time trends specific to each state of incorporation. Tests accounting for state-specific time trends are particularly important in our setting. As Angrist and Pischke (2009) describe, difference-in-difference estimations require the identifying assumption that the counterfactual trends in the treatment and control groups are the same. ${ }^{1}$ Inclusion of a time trend for each state accommodates the possibility that pre- and post-trends in innovation may differ across the treatment and control groups.

Second, to allow for the possibility that the antitakeover law passages may have been triggered by the innovation outcomes of a few influential firms, we control for the maximum and minimum levels of innovation in each year among firms incorporated in the state. Third, we examine the possibility of a spurious correlation between innovation and takeover pressure arising from the facts that: i) all the states enacted laws that reduced takeover pressure, and ii) during our sample

\footnotetext{
${ }^{1}$ Angrist and Pischke ((2009), p. 221) mention that "[difference-in-difference] strategies punt on comparisons in levels, while requiring the counterfactual trend behavior of treatment and control groups to be the same."
} 
period, there was a spur in patenting activity due to the creation of the U.S. Court of Appeals of the Federal Circuit (CAFC) in 1982. For this purpose, we include time trends specific to each 2-digit Standard Industrial Classification (SIC) industry in addition to time trends specific to each state of incorporation. The U-shaped relation remains robust to all the above tests.

Next, we use hand-collected data to conduct tests that are designed to further mitigate the potentially confounding effects of unobserved statewide factors that accompany law passages. We obtain information about patents filed by specific subsidiaries/divisions of firms. In particular, a significant portion of our sample includes patents filed by subsidiaries/divisions that are located outside the parent firm's state of incorporation. Antitakeover laws passed by a state would affect innovation in all of the firm's subsidiaries/divisions. However, any statewide economic changes accompanying the law passage are unlikely to affect the innovation in out-of-state subsidiaries/divisions. By examining innovation undertaken by subsidiaries/divisions that are outside a firm's state of incorporation, we isolate the pure effects of the antitakeover law passages. We find strong empirical support for the U-shaped relation in these tests as well.

We conduct several additional tests to examine the robustness of our empirical findings. First, we do not find evidence of a "reverse causal" relation between antitakeover laws and innovation. Second, we examine the long-run effects of antitakeover law passages on innovation. Intuitively, changes in takeover pressure would have short-term effects on inputs to innovation and long-term effects on outputs. Consistent with this intuition, we indeed find that changes in takeover pressure have the predicted effects on R\&D intensity within 1 year, whereas the effects on patents and citations persist even 3 years after the changes. Third, we show that the U-shaped relation between innovation and the severity of antitakeover laws is robust to controlling for the effects of firm-level antitakeover provisions using the Gompers, Ishii, and Metrick (GIM) (2003) index. Fourth, we demonstrate that our results are not driven by firms incorporated in California, Delaware, and Massachusetts, which represent a significant portion of our sample. Finally, we discuss why our results are unlikely to be affected by the possibility that firms could reincorporate in other states in response to antitakeover law passages.

\section{Related Literature}

We contribute to the theoretical literature that examines the effects of corporate governance mechanisms on innovation. Stein (1988) shows that the threat of a takeover induces managers to behave myopically. Manso (2011) shows that compensation contracts that provide incentives to innovate exhibit the twin features of tolerance for failure in the short term and reward for performance in the long term. Aghion, Van Reenen, and Zingales (2013) find that higher institutional ownership leads to greater innovation. Existing studies thus examine how innovation is affected by either internal mechanisms, such as managerial compensation contracts, or by external mechanisms, such as takeover pressure. Innovation is potentially driven by the interactions among the market for corporate control, contracts, and private benefits. By integrating external and internal governance 
mechanisms, we demonstrate how the interactions between takeover premia and private control benefits lead to the novel prediction that innovation varies in a U-shaped manner with takeover pressure.

Our results are especially pertinent to the ongoing debate on the importance of the market for corporate control in fostering innovation. One strand of the literature (the "quiet life" view) argues that laws that hinder the market for corporate control encourage managerial slack (Jensen (1988)). In contrast, another strand of the literature (the "managerial myopia" view) argues that strong antitakeover laws may foster innovation by facilitating long-term contracting (Shleifer and Summers (1988)) or by encouraging long-term investments by managers (Stein (1988)).

Our theory, which integrates contracting and an external market for corporate control, shows that both perspectives are only "locally" correct. When takeover pressure is above a threshold, a decrease in takeover pressure decreases innovation, which is consistent with the quiet life view. When takeover pressure is below the threshold, a decline in takeover pressure increases innovation, which is consistent with the managerial myopia view. An unhindered market for corporate control fosters innovation through the incentives provided by takeover premia. Severe antitakeover laws may, however, also induce innovation by mitigating the adverse effects of private control benefit losses on managers' incentives to engage in innovative activities. The interplay between the magnitudes of these conflicting forces causes innovation to vary nonmonotonically with takeover pressure.

From an empirical standpoint, our article is related to studies that examine the real effects of corporate governance. Atanassov (2013) empirically examines the quiet life view versus the managerial myopia view using the passage of business combination laws. He, however, tests for a monotonic relation between innovation and takeover pressure and focuses solely on business combination laws. As we discussed earlier, all antitakeover laws are likely to matter in the context of innovation, and we confirm this in our empirical analysis. Our findings that the relation between innovation and takeover pressure is, in fact, nonmonotonic and that other antitakeover laws in addition to business combination laws affect innovation suggest that Atanassov's empirical tests are misspecified and that his results are likely to be affected by omitted variables. Bertrand and Mullainathan (2003) examine the effect of passage of business combination statutes on plantlevel productivity. Bebchuk and Cohen (2005) show that the presence of staggered boards has a detrimental effect on firm value. Giroud and Mueller (2011) examine the differential effects of business combination laws on competitive and noncompetitive industries. We complement these studies by investigating the sequential effects of every antitakeover law.

Another strand of the empirical literature examines the effect of firm-level governance provisions on innovation and equity returns. Meulbroek, Mitchell, Mulherin, Netter, and Poulsen (1990) document a negative correlation between R\&D intensity in firms and the adoption of firm-level antitakeover provisions. Chemmanur and Tian (2012), however, show that firms that adopt a larger number of antitakeover provisions innovate more. Francis and Smith (1995) examine the empirical relation between corporate ownership structure and innovation, and show that diffusely held firms are less innovative than firms with either 
a high concentration of management ownership or a significant equity block held by an outside investor.

Our work also relates to the emerging literature examining the link between financing and innovation. Acharya and Subramanian (2009) find that debtorfriendly bankruptcy laws foster innovation and economic growth, and Acharya, Baghai, and Subramanian (2014) argue theoretically and provide empirical evidence that laws that impose restrictions on dismissal of employees encourage innovation and entrepreneurship. Chava, Oettl, Subramanian, and Subramanian (2013) find that the effect of banking deregulation on innovation depends on the nature of deregulation.

\section{The Model}

We develop a two-period model with dates $0,1,2$. At date 0 , the manager of an all-equity firm chooses between a "more innovative" project, denoted by $H$, and a "less innovative" project, denoted by $L$. Payoffs occur at date 2. All agents are risk neutral and the common discount rate is 0 . The manager is wealth constrained, which precludes the possibility of "selling the firm" to the manager at date 0 .

\section{A. Project Characteristics}

The project $X \in\{H, L\}$ requires an initial investment $C$ and generates a payoff of $P_{X}(2)$ at date $2 .^{2}$ The payoff of project $X \in\{H, L\}$ at date 2 is given by:

$$
P_{X}(2)=2 \mu_{X}+r_{X 1}+r_{X 2}
$$

where $r_{X 1}$ and $r_{X 2}$ are random variables drawn from distributions $R_{X 1}$ and $R_{X 2}$, respectively, with mean 0 . Note that the distributions $R_{X 1}$ and $R_{X 2}$ could differ from each other, and the random variables $r_{X 1}$ and $r_{X 2}$ need not be independent. The random variable $\mu_{X}$ in equation (1) determines the true expected return of the project, which we refer to as the project's quality. There is imperfect but symmetric information about the project's quality. Agents' prior assessment of $\mu_{X}$ is drawn from a distribution $M_{X}$ that has mean $m_{X}$ where

$$
m_{H}>m_{L},
$$

so that the more innovative project has a higher expected payoff. We assume that the random variable $\mu_{X}$ is independent of the random variables $r_{X 1}$ and $r_{X 2}$. We also assume that the distributions $R_{X 1}, R_{X 2}$, and $M_{X}$ are such that the random variables $\mu_{X}+r_{X 1}$ and $\mu_{X}+r_{X 2}$ are almost surely nonnegative. In particular, this implies that the project's payoff $P_{X}(2)$ is almost surely nonnegative.

The parameter $m_{X}$ is the mean quality of the project, and the prior distribution $M_{X}$ is the quality uncertainty of the project. The random variables $r_{X 1}$ and $r_{X 2}$

\footnotetext{
${ }^{2}$ The assumption that the projects require the same initial investment is made purely to simplify the notation. We require only that the more innovative project have a higher net present value than the less innovative project.
} 
capture the first- and second-period intrinsic risks associated with the project, respectively. The project's intrinsic risk is distinct from its quality uncertainty because, although the intrinsic risk is present even if there is perfect information about project quality, quality uncertainty stems from imperfect information about project quality.

\section{B. Intermediate Signals}

The manager's project choice at date 0 is observable. If the manager chooses project $X \in\{H, L\}$ at date 0 , then all agents observe a signal, $P_{X}(1)$, at date 1 that is given by

$$
P_{X}(1)=\mu_{X}+r_{X 1} \text {. }
$$

By comparing equation (3) with equation (1), it is clear that $P_{X}(2)=P_{X}(1)+\mu_{X}+$ $r_{X 2}$, so that the date 1 signal partially resolves the uncertainty about the date 2 payoffs.

Given the signal, all agents update their assessments about the quality of the project chosen by the manager. Let $\widehat{m}_{X}$ denote agents' mean posterior assessment of the project's quality based on their observation of the signal $P_{X}(1)$. We have

$$
m_{X}=\widehat{m}_{X}+s_{X}
$$

where $s_{X}$ is a random variable drawn from the distribution $F_{X}$ with mean 0 . The distribution $F_{X}$ depends on the distributions $M_{X}$ and $R_{X 1}$. We assume that the distribution $F_{X}$ is continuously differentiable with the continuous density $f_{X}$.

\section{More Innovative versus Less Innovative Projects}

The more innovative project $H$ differs from the less innovative project $L$ in three respects. First, the more innovative project has a higher expected return as represented by expression (2).

Second, the distribution of posterior assessments of the quality of the more innovative project has fatter tails, that is,

$$
\begin{aligned}
1-F_{H}(x) & >1-F_{L}(x), \quad \text { for } x>0 \\
F_{H}(y) & >F_{L}(y), \quad \text { for } y<0 .
\end{aligned}
$$

The above conditions imply that the more innovative project is more likely to generate large positive and negative changes in agents' assessments of the project's quality.

Third, the densities $f_{H}(\cdot)$ and $f_{L}(\cdot)$ satisfy the following MLRP:

$$
\frac{f_{H}(u)}{f_{L}(u)},
$$

which is monotonically increasing in $u$ for $u>0$. The MLRP condition implies that a change in agents' mean assessments of project quality is more likely to be generated by the more innovative project as the magnitude of the change increases. 


\section{Private Benefits and Takeover Pressure}

The manager extracts observable but nonverifiable (and, therefore, noncontractible) pecuniary private control benefits $\alpha>0$ provided she still controls the firm in the second period. ${ }^{3}$ At date 1 , the incumbent firm becomes a potential target that can be acquired by a raiding firm through a tender offer. The raider alters the project's quality in the second period. The project's terminal payoff under the raider's control is

$$
P_{X}^{\mathrm{RAIDER}}(2)=P_{X}(1)+\mu_{X}^{\mathrm{RAIDER}}+r_{X 3},
$$

where $r_{X 3}$ is a random variable drawn from the distribution $R_{X 3}$ with mean 0 . As is the case for the project's true expected return under the target firm's management, $\mu_{X}$, the true expected return under the raider, $\mu_{X}^{\mathrm{RAIDER}}$, is also unobservable to all agents in the economy.

We motivate our modeling of takeovers and their effects using the following example. Consider a biotechnology firm that owns patents required for developing antibodies for curing AIDS. The manager as well as the numerous scientists employed in the incumbent firm have specialized human capital required for developing such antibodies. The biotechnology firm becomes the target of a raider, say a pharmaceutical firm that possesses the assets required for conducting clinical trials, manufacturing the drug in a cost-effective manner, and providing a sales and distribution network to sell the drug. The human capital of the raider's manager and its employees (consisting of the scientists, engineers, technicians, and salespeople) are specialized to these assets. In this situation, a takeover brings together other assets that enable the merged firm to manufacture the AIDS drugs successfully. However, if the target firm were to simply replace its manager, it would not be able to access the assets provided by the raider. As a result, simply replacing the target's manager would not enable the target firm to manufacture the AIDS drug.

As in the example, we model takeovers to capture the fact that, in reality, innovation stems from the confluence of both physical assets, which include both tangible assets and intangible assets, and human capital. In particular, human capital includes not just the human capital of the manager but also that of the numerous scientists, engineers, and technicians who play key roles in generating innovation. In general, because the physical assets and the human capital of the manager and the employees are tailored to the project the firm chooses in the first period, these assets acquire some degree of specificity to the project chosen. When a raider takes over the target firm, it brings different (physical and human) assets that cannot, in general, completely replace the (specialized) assets of the target. Furthermore, because physical and human assets are crucial in innovation, the target firm cannot achieve the same outcome by either replacing its current manager or undertaking a fresh project. The firm's physical and human assets have already been committed to its current project and are, therefore, specific to the project to some degree. Through the takeover, the raiding firm merges its assets with those

\footnotetext{
${ }^{3}$ Our results are unaltered if we allow for the manager's private benefits to differ for the two projects (details available from the authors).
} 
of the target firm to potentially alter the firm's project, but it can do so only imperfectly. Accordingly, we assume that the true expected return generated by the raider is

$$
\mu_{X}^{\mathrm{RAIDER}}=(1-\Theta) \mu_{X}+\Theta \nu_{X}^{\mathrm{RAIDER}}=\mu_{X}+\underbrace{\Theta\left(\nu_{X}^{\mathrm{RAIDER}}-\mu_{X}\right)}_{\text {additional return generated by raider }},
$$

where $\Theta \in(0,1]$ is a deterministic constant and $\nu_{X}^{\text {RAIDER }}$ is a random variable that could be viewed as the intrinsic quality of the raider. Equation (8) implies that the true expected return generated by the raider is a convex combination of the intrinsic quality of the target, $\mu_{X}$, and the intrinsic quality of the raider, $\nu_{X}^{\text {RAIDER }}$. Consequently, as illustrated by the example, the return generated by the raider depends on both the quality of the target firm's project and that of the raider. The parameter $\Theta$ represents the "degree of substitutability" between the assets of the target firm and those of the raiding firm.

As in the case of the project's intrinsic quality $\mu_{X}$, there is imperfect but symmetric information about the intrinsic quality of the raider's project, $\nu_{X}^{\text {RAIDER }}$. Furthermore, consistent with the fact that raiders usually belong to the same industry as targets, the raider's project is also drawn from the distribution $M_{X}$. In Appendix B, we show that our implications hold in a generalization of the model in which the raider's project could be drawn from a distribution that differs from that of the original project.

Note that because the intrinsic quality of the raider's project, $\nu_{X}^{\text {RAIDER }}$, could be above or below the intrinsic quality of the project, $\mu_{X}$, equation (8) implies that the raider could create or destroy value. However, we show later that, in equilibrium, a takeover is successful if and only if the return generated by the raider is positive. Equation (8) also implies that the additional return, $\Theta\left(\nu_{X}^{\text {RAIDER }}-\mu_{X}\right)$, generated by the raider depends only on the intrinsic qualities of the raider's and the target firm's projects, and not on the intermediate signal, $P_{X}(1)$, of the firm's project. We later discuss how allowing for the intermediate signal to affect the return generated by the raider could affect our results.

If the raider takes over the firm, the target firm's manager loses her control benefits $\alpha$ to the raider. Antitakeover laws have the common feature that they affect the firm's bargaining power in its negotiations with the raider (see Comment and Schwert (1995)). The more severe the antitakeover laws, the more difficult it is for the raider to take over the firm. We capture the severity of antitakeover laws through the minimum takeover premium, $\eta$, that the raider must offer the firm. More precisely, in the absence of a takeover, the payoff to the firm (shareholders + manager) at date 2 net of the private benefits extracted by the manager is $P_{X}(2)-\alpha$. Hence, the expected payoff to the firm at date 1 net of the manager's private benefits is $\mathrm{E}_{1}\left[P_{X}(2)-\alpha\right]$, where hereafter $\mathrm{E}_{1}(\cdot)$ denotes the expectation conditional on all date 1 information. Let $P_{X}^{\text {TAKEOVER }}$ be the total payoff that the raider offers the firm. If the takeover premium were zero, the raider would have to offer $\mathrm{E}_{1}\left[P_{X}(2)-\alpha\right]$. With a nonzero minimum takeover premium $\eta$, the raider must offer at least $\mathrm{E}_{1}\left[P_{X}(2)-\alpha\right]+\eta$. Therefore, the takeover is successful if and only if

$$
P_{X}^{\mathrm{TAKEOVER}} \geq \mathrm{E}_{1}\left[P_{X}(2)-\alpha\right]+\eta .
$$


The positive relation between the minimum takeover premium and the severity of antitakeover laws is consistent with the evidence in Comment and Schwert (1995) that the passage of antitakeover laws resulted in significant increases in takeover premia.

From expression (9), the payoff, $P_{X}^{\text {TAKEOVER }}$, that the raider offers the firm depends on the expected payoff of the firm's project, $\mathrm{E}_{1}\left[P_{X}(2)\right]$, and the manager's private benefits, $\alpha$. Consequently, the payoff that the firm receives depends on the quality of its project and the first-period signal as well as the manager's private benefits. Note that $\eta$ is the minimum takeover premium that the raider must offer the firm. As we see shortly, the actual takeover premium depends on the expected payoff of the firm's project at date 1 and the intrinsic quality of the raider's project. Because the parameter $\eta$ captures the severity of the antitakeover laws within a state, it is hard to imagine how $\eta$ would depend on a specific firm's project choice and/or intermediate signal $P_{X}(1)$. Thus, although the actual takeover premium is affected by the conditional expected payoff of the firm's project and the intrinsic quality of the raider's project, the minimum takeover premium $\eta$ does not depend on these two effects.

The following proposition shows that for a successful takeover, the value added by the raider must exceed a threshold that depends on the severity of antitakeover laws.

Proposition 1. Likelihood of Takeover and Takeover Payoff. (a) The firm is successfully acquired if and only if

$$
\Theta\left(m_{X}-\widehat{m}_{X}\right) \geq \eta
$$

where $\widehat{m}_{X}$ is the mean posterior project quality at date 1 (see equation (4)).

(b) The total payoff that the firm receives from the raider is

$$
P_{X}^{\text {TAKEOVER }}=\mathrm{E}_{1}\left[P_{X}^{\mathrm{RAIDER}}(2)-\alpha\right]=\widehat{m}_{X}+\Theta\left(m_{X}-\widehat{m}_{X}\right)-\alpha .
$$

(c) The likelihood of a takeover is higher for the more innovative project.

Condition (10) implies that, conditional on the information available to all market participants at date 1 , the takeover is successful if and only if the additional expected return generated by the raider is sufficiently high to compensate for the takeover premium that it must pay the target firm. The condition holds if and only if the posterior mean assessment of project quality $\widehat{m}_{X}$ is sufficiently low, that is, if the firm receives a sufficiently low intermediate signal at date 1. As in studies such as Jensen (1988), Scharfstein (1988), and Stein (1988), therefore, a takeover is successful only if the project underperforms at the intermediate date.

Because the minimum takeover premium $\eta$ that the raider has to offer increases with the severity of antitakeover laws, the threshold project quality (below which a takeover occurs) decreases as antitakeover laws become more severe. Therefore, an increase in the severity of antitakeover laws lowers the takeover pressure faced by a target firm.

From expression (11), note that the payoff that the raider pays to the firm depends on the intrinsic quality of the firm's project and its posterior assessment 
at date 1 . Furthermore, it declines with the manager's private benefits $\alpha$. Condition (c) of Proposition 1 implies that the likelihood of a takeover is higher for the more innovative project. Because the posterior assessments of the quality of the more innovative project are more variable, they are more likely to generate significantly bad signals in the interim, which increases the likelihood of a takeover.

The prediction of Proposition 1 that more innovative firms are more likely to underperform in the interim and are consequently more likely to be taken over is consistent with empirical evidence. Desyllas and Hughes (2009) analyze the acquisitions of publicly traded high-technology firms over 1984-1998. They find that, compared to nonacquired firms, acquired firms are more innovative but they experience poor profitability before being taken over.

Our focus on "disciplinary" takeovers in the basic model, in which underperforming firms are taken over, is consistent with Jensen (1988), Scharfstein (1988), and Stein (1988). Nevertheless, in Appendix B, we show that under some additional conditions, our main results are robust to a setting that accommodates both "disciplinary" and "synergistic" takeovers. In that setting, the acquiring firm's project could either substitute the target firm's project, which is characteristic of disciplinary takeovers, or complement the target firm's project, which is characteristic of synergistic takeovers (see Auerbach (1988)). In a synergistic takeover, overperforming firms are taken over because of potential synergies with an acquiring firm. In the extended model, therefore, both significantly underperforming and overperforming firms could be taken over.

\section{E. Contracting}

At date 0 , the manager and the shareholders enter into a long-term contract. The contract cannot prevent the pool of widely dispersed shareholders at date 1 from tendering their shares to a raider if it is in their interests to do so. However, the contract can specify a severance payment to the manager in the event of a takeover at date 1 . The manager's project choice $X$, her private control benefits $\alpha$, and the date 1 signal $P_{X}(1)$ are all observable but not verifiable and, therefore, noncontractible. However, the date 2 net cash flows of the firm if it is not taken over (i.e., $P_{X}(2)-\alpha$ ) and the firm's date 1 net cash flows if it is taken over (i.e., $P_{X}^{\text {TAKEOVER }}$ ) are both contractible. At date 0 , the shareholders can therefore write a compensation contract contingent on the contractible cash flows. Denote this compensation contract by $w\left(Q_{X}\right)$, where $Q_{X}$ denotes the contractible portion of the firm's cash flows and is given by

$$
\begin{aligned}
Q_{X} & \equiv P_{X}(2)-\alpha, \quad \text { if the firm is not taken over at date } 1 \\
& \equiv P_{X}^{\text {TAKEOVER }}, \quad \text { if the firm is taken over at date } 1 .
\end{aligned}
$$

\section{Main Implications}

In this section, we derive the main results of the article and generate the empirical implications. 


\section{A. Benchmark Environment}

It is useful to analyze the benchmark environment in which there are no frictions; that is, the project choice $X$ is contractible, and the manager derives no private control benefits (i.e., $\alpha=0$ ). In this environment, the manager chooses the project $X^{\text {BENCHMARK }}$ that maximizes the total expected payoff of the firm so that:

$$
\begin{aligned}
X^{\mathrm{BENCHMARK}}= & \underset{X \in\{H, L\}}{\arg \max } \mathrm{E}[\underbrace{1_{X}^{\mathrm{NO}} \mathrm{TAKEOVER} \cdot P_{X}(2)}_{\text {payoff if no takeover }}] \\
& +\mathrm{E}[\underbrace{1_{X}^{\mathrm{TAKEOVER}} \cdot P_{X}^{\mathrm{TAKEOVER}}}_{\text {payoff if takeover occurs }}]
\end{aligned}
$$

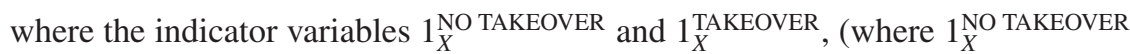
$+1_{X}^{\text {TAKEOVER }}=1$ ) represent the events that the firm that has undertaken if project $X$ is not taken over and is taken over, respectively, at date 1 (the subscript indicates that the event of being taken over depends on the project $X$ ).

In the benchmark environment, the shareholders maximize their expected payoff by extracting all the surplus from the raider at date 1 and the raider earns zero profits. Therefore, $P_{X}^{\mathrm{TAKEOVER}}=\mathrm{E}_{1}\left[P_{X}^{\mathrm{RAIDER}}(2)\right]$, where $\mathrm{E}_{1}[\cdot]$ denotes the expectation operator with respect to date 1 information. Substituting for $P_{X}^{\mathrm{TAKEOVER}}=\mathrm{E}_{1}\left[P_{X}^{\mathrm{RAIDER}}(2)\right]$ in (13) and using the law of iterated expectations,

$$
\begin{aligned}
X^{\mathrm{BENCHMARK}}= & \underset{X \in\{H, L\}}{\arg \max } \underbrace{\mathrm{E}_{1}\left(P_{X}(2)\right)}_{\text {expected unconditional payoff }} \\
& +\underbrace{\mathrm{E}_{1}\left[1_{X}^{\mathrm{TAKEOVER}} \cdot\left(P_{X}^{\mathrm{RAIDER}}(2)-P_{X}(2)\right)\right]}_{\text {expected takeover premium }} .
\end{aligned}
$$

By equation (14), the total expected payoff to the firm equals the sum of the expected unconditional payoff and the expected takeover premium. Note that because the firm can be taken over only if the raider offers a positive premium, the expected takeover premium term is strictly positive. The following proposition shows that the manager always chooses greater innovation in the benchmark scenario.

Proposition 2. Benchmark Project Choice. In the benchmark environment with no frictions, the manager always chooses the more innovative project.

The more innovative project has a higher expected unconditional payoff than the less innovative project. Furthermore, by Proposition 1(c), the takeover likelihood is greater for the more innovative project. Because the posterior assessments of the quality of the more innovative project are more variable, the takeover premia conditional on a takeover are more likely to take larger values. Consequently, the expected takeover premium on the right-hand side of equation (14) is also higher for the more innovative project. Therefore, the manager optimally chooses the more innovative project. 


\section{B. Optimal Project Choice}

We now analyze the environment in which the manager's project choice is noncontractible and she derives nonzero private benefits $\alpha$. At date 0 , to maximize their expected payoff, the shareholders design an optimal compensation contract $w^{*}\left(Q_{X}\right)$ for the manager, where $Q_{X}$ is the contractible payoff defined in expression (12). The optimal project choice $X^{*} \in\{H, L\}$ and the manager's compensation contract $w^{*}\left(Q_{X}\right)$ solve the following optimization problem:

$$
\begin{aligned}
\left(X^{*}, w^{*}\left(Q_{X}\right)\right) \equiv & \underset{X, w\left(Q_{X}\right)}{\arg \max } \mathrm{E}\left[Q_{X}-w\left(Q_{X}\right)\right] \\
\text { s.t. } \quad & \mathrm{E}\left[\left(1_{X}^{\mathrm{NO} T A K E O V E R}\right) \cdot \alpha+w\left(Q_{X}\right)\right] \geq U, \\
& w\left(Q_{X}\right)+\left(1_{X}^{\mathrm{NO} T A K E O V E R}\right) \cdot \alpha \geq 0 \text { a.e. } \\
X= & \underset{X^{\prime} \in\{H, L\}}{\arg \max } \mathrm{E}\left[\left(1_{X^{\prime}}^{\mathrm{NO} T A K E O V E R}\right) \cdot \alpha+w\left(Q_{X^{\prime}}\right)\right],
\end{aligned}
$$

where expressions (16), (17), and (18) refer to the manager's participation, limited liability, and incentive compatibility constraints, respectively. Note that the manager derives the private benefit $\alpha$ if and only if the firm is not taken over. In expression (16), $U$ denotes the manager's reservation payoff. Throughout our analysis we make the reasonable assumption that the reservation payoff of the manager is greater than the amount of private benefit the manager can extract (i.e., $U>\alpha$ ). As we show in Appendix A, this assumption, in turn, implies that the manager's limited liability constraint (17) does not bind under the optimal contract.

The following proposition describes the manager's optimal project choice.

Proposition 3. The manager's optimal project choice $X^{*}$ solves

$$
\begin{aligned}
\underset{X \in\{H, L\}}{\arg \max } & \overbrace{\mathrm{E}\left(P_{X}(2)\right)}^{\text {expected unconditional payoff }} \\
& +\overbrace{\mathrm{E}\left[1_{X}^{\text {TAKEOVER }} \cdot\left(P_{X}^{\text {RAIDER }}(2)-P_{X}(2)\right)\right]}^{\text {expected takeover premium }} \\
& -\overbrace{\mathrm{E}\left[1_{X}^{\text {TAKEOVER }} \cdot \alpha\right]}^{\text {expected control benefits loss }} \\
= & \underset{X \in\{H, L\}}{\arg \max 2 m_{X}+\int_{\frac{\eta}{\Theta}}^{\infty} \Theta u f_{X}(u) d u-\alpha\left[1-F_{X}\left(\frac{\eta}{\Theta}\right)\right] .}
\end{aligned}
$$

By expression (19), in the presence of private control benefits, the manager's optimal project choice maximizes the expected unconditional payoff $\mathrm{E}\left(P_{X}(2)\right)$ plus the expected takeover premium less the expected control benefits the manager loses to the raider in the event of a takeover. Recall that in the benchmark environment with no frictions, equation (14) implies that the manager maximizes the total expected payoff of the firm given by the first two terms of expression (19). 
However, in our second-best environment, in which the project choice is not contractible and the manager derives private benefits, the manager maximizes the total expected payoff of the firm minus the expected loss in control benefits due to a possible takeover at date 1 .

The objective function in expression (20) illustrates the basic trade-off the manager faces in choosing the degree of innovation. From Proposition 1(c), the likelihood of being taken over is higher for the more innovative project. Hence, the manager's expected loss of control benefits is also higher. However, as discussed at the end of Section IV.A, the more innovative project also has a larger expected takeover premium. The manager's project choice of high versus low innovation must therefore trade off the positive effect of high innovation on the expected unconditional payoff and the expected takeover premium against the negative effect of high innovation on the expected loss of control benefits.

We now discuss the key feature of our model that generates the trade-off described by Proposition 3. By equation (11), the actual takeover premium paid by the raider is

$$
\begin{aligned}
P_{X}^{\mathrm{TAKEOVER}}-\mathrm{E}_{1}\left[P_{X}(2)-\alpha\right] & =\mathrm{E}_{1}\left[P_{X}^{\mathrm{RAIDER}}(2)-P_{X}(2)\right] \\
& =\Theta\left(m_{X}-\widehat{m}_{X}\right) .
\end{aligned}
$$

Consequently, the actual takeover premium increases as the mean posterior assessment of the quality of the incumbent project, $\widehat{m}_{X}$, declines because a raider can potentially add greater value in such a scenario. As we discuss above, the higher likelihood of a takeover associated with the more innovative project along with the greater variability in posterior assessments of project quality of the more innovative project combines to cause the expected takeover premium to be higher for the more innovative project. This, in turn, makes it optimal for the manager to choose the more innovative project when takeover pressure is very high. More generally, the key feature that is needed to generate the trade-off described by Proposition 3 is that the likelihood of a takeover and the expected takeover premium are both higher for the more innovative project.

Note that by assumption, the additional return $\Theta\left(\nu_{X}^{\text {RAIDER }}-\mu_{X}\right)$ generated by the raider does not depend on the interim signal $P_{X}(1)$. Suppose, on the other hand, the additional return generated by a raider decreases as the interim signal $P_{X}(1)$ decreases so that the actual takeover premium declines as $\widehat{m}_{X}$ declines. In this scenario, depending on the distributions $F_{H}$ and $F_{L}$ and the rate of decline of the actual takeover premium with $\widehat{m}_{X}$, it could be that the less innovative project is more likely to be taken over and the expected takeover premium is higher so that choosing lower innovation is optimal when takeover pressure is very high. However, the evidence in Desyllas and Hughes (2009) discussed earlier that more innovative firms are more likely to be taken over, but they experience poor profitability before being taken over, does not accord well with these predictions. Empirical and anecdotal evidence, therefore, more easily conforms to our perspective where the takeover likelihood and the expected takeover premium are higher for the more innovative project, which is what we need to generate the trade-offs between low and high innovation. 


\section{Optimal Compensation Contract}

Proposition 4. Optimal Contract. An optimal contract for the manager is one in which she receives a fraction $\lambda$ of the firm's terminal payoffs (i.e., $\lambda Q_{X^{*}}$ ) and an additional payment, $\beta$, if the firm is taken over where $\beta=(1-\lambda) \alpha$, and $\lambda$ is chosen to satisfy the manager's participation constraint at equality:

$$
U=2 m_{X^{*}} \lambda+(1-\lambda) \alpha+\lambda \int_{\frac{\eta}{\Theta}}^{\infty} \Theta u f_{X^{*}}(u) d u-\lambda \alpha\left[1-F_{X^{*}}\left(\frac{\eta}{\Theta}\right)\right]
$$

where $X^{*}$ is the optimal project choice that satisfies expression (20).

The optimal allocation of payoffs to the shareholders and the manager can be implemented in different ways. In the above implementation, the manager receives a (restricted) equity stake of $\lambda$ in the firm along with a severance payment of $\beta>0$ if the firm is taken over. Because the manager loses her control benefits in the event of a takeover, the severance payment partially compensates her by providing a proportion $(1-\lambda)$ of the control benefits. From an ex ante perspective, the equity stake $\lambda$ and the severance payment $\beta$ are contractual devices that align the manager's incentives with those of the shareholders. The severance payment resembles a firm-level antitakeover device (such as a golden parachute or a poison pill) in that it makes a takeover costlier.

Note that, as is standard in incomplete contracting models in which private benefits are observable but noncontractible (e.g., Bebchuk and Jolls (1999), Tirole ((2006), ch. 3)), the contractual parameters such as the equity stake $\lambda$ and the severance payment $\beta$ do depend on $\alpha$. This reflects the fact that shareholders incorporate their knowledge of the value of $\alpha$ in designing the manager's contract. The contractual compensation $w^{*}\left(Q_{X}\right)$ is, however, directly contingent on the contractible variable $Q_{X}$ and not on the manager's private benefits. If private benefits were contractible, $w^{*}(\cdot)$ could be made directly contingent on the amount of private benefits the manager extracts. In this case, the first-best outcome would be achieved via a compensation contract that imposes a severe penalty on the manager if she extracts nonzero private benefits.

\section{Innovation, External Takeover Pressure, and Private Benefits}

We now describe the effects of takeover pressure on the degree of innovation.

Proposition 5. Effect of Takeover Pressure on Innovation. There exists an interval $\left[\eta_{\min }, \eta_{\max }\right]$ of the external takeover pressure parameter $\eta$ such that the manager chooses the more innovative project for $\eta \notin\left[\eta_{\min }, \eta_{\max }\right]$ and the less innovative project for $\eta \in\left[\eta_{\min }, \eta_{\max }\right]$.

Proposition 5 implies there is a U-shaped relation between innovation and the level of takeover pressure. To understand why this U-shaped relation arises, consider the case where the external takeover pressure is very low $\left(\eta>\eta_{\max }\right)$. In this case, a takeover is very unlikely, so the expected takeover premium and the expected loss in control benefits are insignificant for both projects. 
Therefore, the manager chooses the more innovative project because it has a greater expected unconditional payoff. When takeover pressure is very high $(\eta<$ $\left.\eta_{\min }\right)$, the takeover probabilities are similar for both projects so that the expected losses of control benefits are also similar. However, as seen in Proposition 2, the expected takeover premium is higher for the more innovative project because it depends not only on the probability of a takeover but also on the size of the takeover premium conditional on a takeover. Consequently, it is again optimal to choose the more innovative project. In contrast, for moderate levels of takeover pressure, the difference in the expected losses of control benefits associated with the two projects is significant and dominates the difference in the expected takeover premia plus the difference in the expected unconditional payoffs. Therefore, the manager chooses the less innovative project.

We now describe the effect of the level of private benefits on the degree of innovation.

Proposition 6. Effect of Private Benefits on Innovation. The interval $\left[\eta_{\min }(\alpha)\right.$, $\left.\eta_{\max }(\alpha)\right]$, for which the manager chooses lower innovation, increases as private control benefits $\alpha$ increase. More precisely,

$$
\left[\eta_{\min }\left(\alpha_{1}\right), \eta_{\max }\left(\alpha_{1}\right)\right] \subset\left[\eta_{\min }\left(\alpha_{2}\right), \eta_{\max }\left(\alpha_{2}\right)\right], \quad \text { for } 0<\alpha_{1}<\alpha_{2}
$$

In the intermediate interval $\left[\eta_{\min }(\cdot), \eta_{\max }(\cdot)\right]$, the relative effect of the manager's expected loss of control benefits on her project choice is high, and thus she chooses the less innovative project. As the manager's control benefits increase, the potential losses she might incur due to a takeover also increase, and so the interval over which she chooses lower innovation expands.

If the firm has a higher proportion of ownership by outside blockholders, the manager will be better monitored so that the private benefits that she can extract are likely to be lower (Tirole (2006)). In other words, better monitoring of the manager increases the verifiable portion of the firm's total earnings, thereby limiting the manager's private benefits. Thus, Proposition 6 implies that the degree of innovation increases with outside blockholder/institutional ownership; a prediction that is supported by recent empirical evidence (see Aghion et al. (2013)).

Our results, and the intuition underlying them, show that some of the key characteristics of innovation play important roles in generating the U-shaped relation between innovation and takeover pressure. Innovation is usually associated with uncertainty stemming from exploration, which we capture in our framework through imperfect information about the quality of the project. Uncertainty about the quality of the project as well as the effects of the interim signal on agents' posterior assessments is crucial to our results. If there were no uncertainty about the quality of the projects, the interim signal would affect neither the likelihood of a takeover nor the expected takeover premium. Consequently, the ex ante project choice would not be affected by takeover pressure. In particular, if one project were merely riskier than the other, but the quality of the projects was not uncertain, we would not obtain a corresponding U-shaped relation between risk and takeover pressure. 


\section{Empirical Analysis}

We exploit the staggered passage of antitakeover laws across U.S. states to examine our hypothesis that the relation between the degree of innovation and takeover pressure is U-shaped; that is, innovation falls with takeover pressure when it is relatively low and increases with takeover pressure when it is relatively high.

\section{A. Sample and Proxies}

\section{Proxies for Innovation}

We employ both ex ante and ex post measures to proxy firm-level innovation. We use $R \& D$ intensity, that is, the ratio of a firm's $R \& D$ expenditures to sales, as our ex ante measure of innovation. To construct our ex post measures of innovation, we use data compiled in the National Bureau of Economic Research (NBER) Patents File (Hall et al. (2001)) on patents filed with the U.S. Patent and Trademark Office as well as the subsequent citations to these patents. The NBER patent data set provides (among other items) annual information on patent assignee names, the number of patents, the number of citations received by each patent until 2002, and the year the patent application is filed. We use only patents filed by U.S. firms for our analysis. To link the patent data with Center for Research in Security Prices (CRSP)/Compustat, we exploit the fact that each assignee in the NBER patent data set is given a unique and time-invariant identifier. $^{4}$

We use four metrics for our ex post measures of innovation. First, we employ a simple count of the number of patents that were filed by a firm in a particular year. Second, to capture the economic value of the innovation by distinguishing between breakthrough and incremental innovations, we measure all subsequent citations (until 2002) made to these patents (see Griliches, Pakes, and Hall (1987)). Although the patents appear in the database only after they are granted, we follow the literature in dating the patents by the year in which they were applied for because the year of application captures the relevant date of the innovation. ${ }^{5}$ This also avoids any anomalies that may be caused by the time lag between the application date and the grant date of a patent. Finally, we employ the number of patents and citations per dollar of R\&D to investigate the effect of changes in takeover pressure on the efficiency of investments in innovation.

\footnotetext{
${ }^{4}$ To match these assignee names to the firm identifier in the CRSP/Compustat data (GVKEY), we use the recent GVKEY-assignee match provided for the NBER data, which has the advantage of taking into account the effect of mergers and acquisitions to map the patents to the appropriate entity (see http://eml.berkeley.edu/ bhhall/patents.html). We augment the NBER match with the match we generated on our own. To generate our GVKEY-assignee match, we first match the patent assignee names to those of divisions and subsidiaries belonging to a corporate family from the Directory of Corporate Affiliations. Using this corporate family, we then match the patent assignee to the GVKEY corresponding to the corporate parent in CRSP/Compustat. We do this matching using name-matching algorithms together with manual verification of $5 \%$ of the matched pairs.

${ }^{5}$ We identify patents filed by U.S. subsidiaries of foreign firms as those where the country of the "assignee" is non-United States but the country of the "inventor" is the United States. Of all the patents in our sample, close to $2.0 \%$ were issued to U.S. subsidiaries of foreign companies. Excluding these patents does not change our results.
} 


\section{Proxies for External Takeover Pressure}

We use the state-level index of antitakeover laws compiled by Bebchuk and Cohen (2003) as the proxy for takeover pressure. The index attaches to each state a score from 0 to 5 that is equal to the number of antitakeover statutes passed by the state. (See Bebchuk and Cohen (2003) for detailed descriptions of these statutes.)

In Figure 1, we show the evolution of the antitakeover index for all the states in our sample. Table 1 shows the years of law passages, the antitakeover index before each law passage, and the change in the index after the law passage. ${ }^{6}$ The figure and table show that both the levels and changes of the antitakeover index exhibit considerable variation across time and across states.

\section{FIGURE 1}

\section{Cross-Sectional and Time-Series Variation in the Antitakeover Index}

Figure 1 shows the evolution of the antitakeover index for all states in our sample in which firms are incorporated.

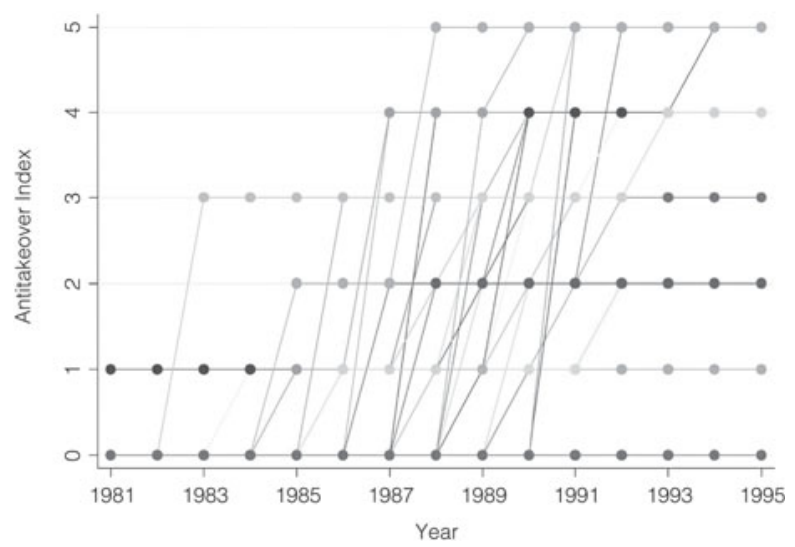

Because the first antitakeover law was passed in 1983 and the last law was passed in 1992, we restrict our sample period from 1980 to 1995, which is identical to the sample periods used by Bertrand and Mullainathan (2003) and Giroud and Mueller (2011). Furthermore, ending the sample in 1995 mitigates problems stemming from "truncation bias" in citations, that is, bias resulting from the fact that citations to recent patents may not have accumulated yet. Our final sample consists of 61,470 firm-year observations for the number of patents and citations. Given the missing values in CRSP/Compustat for R\&D, we have 44,674 firm-year observations for R\&D/Sales.

\footnotetext{
${ }^{6}$ We compiled this list of changes by combining the antitakeover index from Bebchuk and Cohen (2003) with the list of law passages compiled by Bertrand and Mullainathan (2003) and Karpoff and Malatesta (1989). Although we rely primarily on Bebchuk and Cohen (2003) for the list of law passages, we cross-checked the year of passage of these laws using the lists provided in Bertrand and Mullainathan (2003) and Karpoff and Malatesta (1989). In those instances where the year of passage of the law did not coincide across these three studies, we cross-checked the year using the LexisNexis annotated state statutes.
} 
TABLE 1

Changes in Antitakeover Laws over Time and across States in the Sample

Table 1 shows the year(s) in which antitakeover laws were passed in each state, the value of the index before the change and the change in the index. We compiled this list of changes by combining the antitakeover index from Bebchuk and Cohen (2003) with the lists of law passages compiled by Bertrand and Mullainathan (2003) and by Karpoff and Malatesta (1989). While we relied primarily on Bebchuk and Cohen (2003) for the list of law passages, we cross-checked the year of passage of these laws using the list provided in Bertrand and Mullainathan (2003) and Karpoff and Malatesta (1989). In those instances where the year of passage of the law did not coincide across these three studies, we cross-checked the year using the annotated state statutes from LexisNexis.

\begin{tabular}{|c|c|c|c|c|c|c|c|}
\hline State & Year & Index before & Change & State & Year & Index before & Change \\
\hline Colorado & 1989 & 0 & 1 & North Carolina & 1987 & 0 & 2 \\
\hline Connecticut & 1984 & 0 & 1 & North Carolina & 1990 & 2 & 1 \\
\hline Connecticut & 1989 & 1 & 1 & Nebraska & 1988 & 0 & 2 \\
\hline Delaware & 1988 & 0 & 1 & New Jersey & 1986 & 0 & 2 \\
\hline Florida & 1987 & 0 & 2 & New Jersey & 1989 & 2 & 2 \\
\hline Florida & 1989 & 2 & 2 & Nevada & 1987 & 0 & 1 \\
\hline Georgia & 1985 & 0 & 1 & Nevada & 1989 & 1 & 1 \\
\hline Georgia & 1988 & 1 & 1 & Nevada & 1991 & 2 & 3 \\
\hline Georgia & 1989 & 2 & 2 & New York & 1985 & 0 & 3 \\
\hline lowa & 1989 & 0 & 2 & New York & 1989 & 3 & 1 \\
\hline Illinois & 1984 & 0 & 2 & Ohio & 1982 & 0 & 3 \\
\hline Illinois & 1989 & 2 & 2 & Ohio & 1990 & 3 & 2 \\
\hline Indiana & 1986 & 0 & 4 & Oklahoma & 1987 & 0 & 1 \\
\hline Indiana & 1989 & 4 & 1 & Oregon & 1987 & 0 & 1 \\
\hline Kansas & 1988 & 0 & 1 & Oregon & 1989 & 1 & 2 \\
\hline Massachusetts & 1987 & 0 & 1 & Oregon & 1991 & 3 & 1 \\
\hline Massachusetts & 1989 & 1 & 3 & Pennsylvania & 1988 & 0 & 1 \\
\hline Maryland & 1983 & 0 & 1 & Pennsylvania & 1989 & 1 & 3 \\
\hline Maryland & 1988 & 1 & 1 & Pennsylvania & 1993 & 4 & 1 \\
\hline Maryland & 1989 & 2 & 1 & Rhode Island & 1990 & 0 & 4 \\
\hline Michigan & 1984 & 0 & 1 & South Carolina & 1988 & 0 & 3 \\
\hline Michigan & 1988 & 1 & 1 & Tennessee & 1988 & 0 & 4 \\
\hline Michigan & 1989 & 2 & 1 & Tennessee & 1989 & 4 & 1 \\
\hline Minnesota & 1984 & 0 & 1 & Utah & 1987 & 0 & 1 \\
\hline Minnesota & 1987 & 1 & 2 & Utah & 1989 & 1 & 1 \\
\hline Minnesota & 1991 & 3 & 1 & Virginia & 1985 & 0 & 1 \\
\hline Missouri & 1984 & 0 & 1 & Virginia & 1988 & 1 & 2 \\
\hline Missouri & 1986 & 1 & 3 & Virginia & 1992 & 3 & 1 \\
\hline Mississippi & 1985 & 0 & 1 & Washington & 1987 & 0 & 2 \\
\hline Mississippi & 1990 & 1 & 1 & Wisconsin & 1984 & 0 & 2 \\
\hline Mississippi & 1991 & 2 & 1 & Wisconsin & 1987 & 2 & 3 \\
\hline
\end{tabular}

Table 2 shows the summary statistics for our various proxies. The average firm in our sample invests $10 \%$ of its annual sales revenue in R\&D, applies for and is granted 5.0 patents per year, and subsequently receives about 49.2 citations per year. Table 3 lists the states in which firms in our sample are incorporated as well as the number of firm-year observations contributed by the various states.

TABLE 2

Summary Statistics

Table 2 displays summary statistics for the proxies for innovation as well as the key explanatory variables. Because the unit of observation is a firm-year, all the summary statistics are computed at the firm-year level of aggregation.

\begin{tabular}{|c|c|c|c|c|c|}
\hline Variable & $N$ & Mean & Max. & Min. & Std. Dev. \\
\hline R\&D/Sales & 44,674 & 0.10 & 0.83 & 0.00 & 0.20 \\
\hline Patents & 61,470 & 5.00 & $2,205.00$ & 0.00 & 32.66 \\
\hline Citations & 61,470 & 49.21 & $21,127.00$ & 0.00 & 357.34 \\
\hline Antitakeover index & 61,470 & 0.95 & 5.00 & 0.00 & 1.35 \\
\hline Competition & 61,470 & 0.98 & 1.00 & 0.00 & 0.02 \\
\hline Assets (\$million) & 61,470 & 781.40 & $251,506.00$ & 0.00 & $5,725.98$ \\
\hline Sales (\$million) & 61,470 & 797.29 & $165,370.20$ & 0.00 & $4,556.04$ \\
\hline Blockholder share & 61,470 & 0.02 & 0.81 & 0.00 & 0.07 \\
\hline Industry Tobin's Q & 61,470 & 2.77 & 151.97 & 0.85 & 6.35 \\
\hline
\end{tabular}


TABLE 3

State of Incorporation of Firms in the Sample

Table 3 shows the number of firm-year observations in for the various states of incorporation.

\begin{tabular}{|c|c|c|c|}
\hline State & $N$ & State & $N$ \\
\hline Delaware & 36,285 & Pennsylvania & 1,635 \\
\hline California & 2,910 & Ohio & 1,530 \\
\hline New York & 2,490 & New Jersey & 1,275 \\
\hline Massachusetts & 2,190 & Others & 15,645 \\
\hline Minnesota & 1,950 & & \\
\hline
\end{tabular}

\section{B. Basic Tests}

Figure 2 provides visual evidence of the predicted U-shaped relation by showing the effects of the passage of antitakeover laws in Delaware in 1988 and Indiana in 1989. Because California did not pass an antitakeover law over the entire sample period, firms incorporated in California serve as the control group. The left and right panels in Figure 2 show the effects of the law passages in Delaware and in Indiana, respectively. To net out the effects of firm-specific factors and general trends in innovation, we plot on the $y$-axis the residuals from a regression of the logarithm of the number of patents/citations on firm and year dummies. To enable comparison, we normalize the $y$-variable to 0 in the year after

\section{FIGURE 2}

Difference-in-Difference Effect on Innovation of Passage of Antitakeover Laws in Delaware and Indiana Using Firms Incorporated in California as the Control Group

In Figure 2, the $y$-axis plots the residuals from a regression of the log of patents/citations on firm and year fixed effects. To enable visual interpretation, we normalize the residuals to 0 for the year after the change (1989 for Delaware and 1990 for Indiana) by subtracting the value of the residual in the year after the change for each state. The value of the index before the change is 0 for Delaware and 4 for Indiana.

Graph A. Delaware vs. California, Patents

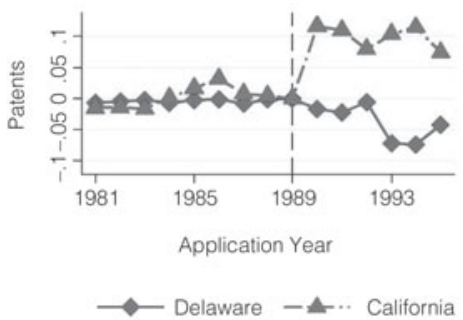

Graph C. Delaware vs. California, Citations

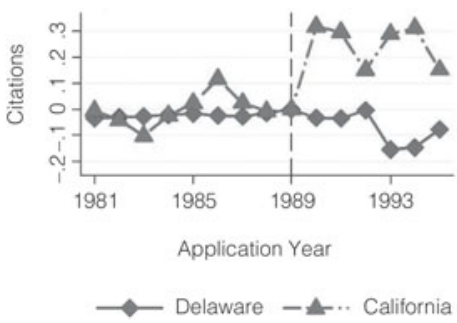

Graph B. Indiana vs. California, Patents

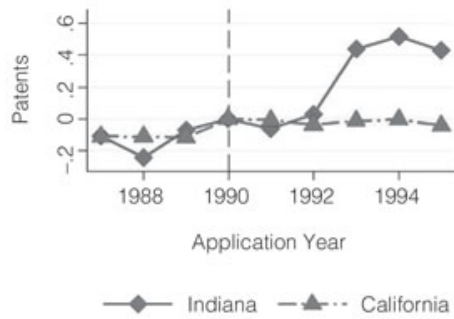

Graph D. Indiana vs. California, Citations

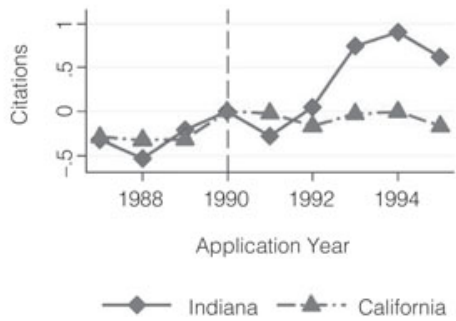


the law passage for both the control and treatment groups by subtracting the value for the respective group in the year after the law passage.

In Graphs A and C of Figure 2, we observe that until 1989, innovation by firms incorporated in Delaware closely resembles that by firms incorporated in California. However, from 1990 onward (2 years after the law passage in 1988 in Delaware), firms incorporated in Delaware innovate significantly less than those incorporated in California. In contrast, in Graphs B and D of Figure 2, we observe that although firms incorporated in Indiana and California innovate similarly until 1991, from 1992 onward firms incorporated in Indiana exhibit a significant break and innovate considerably more than firms incorporated in California. Because the values of the antitakeover index before the change were 0 and 4 for Delaware and Indiana, respectively, and both states passed one antitakeover statute, changes in takeover pressure in these two states fall at the opposite extremes of takeover pressure. The relatively decreased innovation by firms incorporated in Delaware and the increased innovation by firms incorporated in Indiana are consistent with the U-shaped relation predicted by our theory.

We now more rigorously examine the relation between innovation and antitakeover laws using the following fixed-effects panel regression:

$$
y_{i s, t+1}=\beta_{i}+\beta_{t+1}+\beta_{1} \mathrm{TI}_{s t}+\beta_{2} \mathrm{TI}_{s t}^{2}+\beta X_{i s t}+\varepsilon_{i s, t+1},
$$

where $y_{i s, t+1}$ is the measure of innovation for firm $i$ incorporated in state $s$ in year $t+1$, and $\mathrm{TI}_{s t}$ denotes the antitakeover index for state $s$ at the end of year $t$. We examine the effects of the passage of antitakeover laws with a time lag of 1 year because states may pass antitakeover laws in any month of the year. Because the antitakeover index varies with the state and the year, we estimate robust standard errors that are clustered by state-year.

The variables $\beta_{t+1}$ and $\beta_{i}$ in equation (23) denote year and firm fixed effects, respectively. The year fixed effects control for intertemporal differences in innovation that are constant across states and industries as well as problems stemming from the truncation bias in citations. The firm fixed effects control for time-invariant unobserved determinants of innovation at the firm level. Because most firms do not change their state of incorporation or their primary industry, the firm fixed effects also capture time-invariant, unobserved determinants at the state and industry levels. These fixed effects enable us to control for the possibility that differences in innovation are driven by differences in the comparative advantages of firms located in some specific states.

Panel A of Table 4 reports the results of estimating (23). In columns 1-3, we estimate expression (23) without any control variables. In column 1, we use $\mathrm{R} \& \mathrm{D} / \mathrm{Sales}$ as the dependent variable. Here, and in all subsequent regressions, we winsorize R\&D/Sales at the 5\% and 95\% levels. In columns 2 and 3, we undertake OLS regressions using the logarithm of 1 plus patents and 1 plus citations, respectively, instead of the negative binomial or Poisson models. Although our results are similar using these specifications, the identifying assumptions required in nonlinear models are restrictive in practice (Wooldridge (2002), p. 675). Furthermore, interpreting the marginal effect $\partial y_{i s, t+1} / \partial \mathrm{TI}_{s t}=\beta_{1}+\beta_{2} \mathrm{TI}_{s t}$, especially that of the coefficient $\beta_{2}$, is problematic in these nonlinear models (see Lel and 


\section{TABLE 4}

\section{Effect of Takeover Pressure on R\&D Intensity, Patents, and Citations}

Panel A of Table 4 implements the following regression:

$$
y_{i s, t+1}=\beta_{i}+\beta_{t+1}+\beta_{1} \mathrm{Tl}_{s t}+\beta_{2} \mathrm{Tl}_{s t}^{2}+\beta X_{i s t}+\varepsilon_{i s, t+1} .
$$

Columns $1-3$ and $4-6$ in Panel B of Table 4 implement the following regressions, respectively:

$$
\begin{aligned}
y_{i s, t+1}= & \beta_{i}+\beta_{t+1}+\beta_{1} \mathrm{Tl}_{s t}\left(\mathrm{Tl}_{s t} \leq k\right)+\beta_{2} \mathrm{Tl}_{s t}\left(\mathrm{Tl}_{s t}>k\right)+\varepsilon_{i s, t+1}, \\
y_{i s, t+1}= & \beta_{i}+\beta_{t+1}+\beta_{1} \mathrm{Tl}_{s t}\left(\mathrm{Tl}_{s t} \leq k_{1}\right)+\beta_{2} \mathrm{Tl}_{s t}\left(k_{1}<\mathrm{Tl}_{s t}<k_{2}\right) \\
& +\beta_{3} \mathrm{Tl}_{s t}\left(\mathrm{Tl}_{s t} \geq k_{2}\right)+\varepsilon_{i s, t+1},
\end{aligned}
$$

where $k=2$ while $k_{1}=1$ and $k_{2}=4$. The variable $y_{i s, t+1}$ is a measure of innovation in year $t+1$ for firm $i$ incorporated in state $s$. The variable $\mathrm{Tl}_{s t}$ equals the value of the antitakeover index in state $s$ at the end of year $t$. The variables $\beta_{i}$ and $\beta_{t+1}$ denote firm and year fixed effects, respectively. The knot point $k$ for the piecewise linear tests is set at $\mathrm{TI}_{s t}=2$ in the tests below. $X_{i s t}$ denotes the set of control variables. All regressions are estimated using ordinary least squares. The standard errors in parentheses are robust to both heteroskedasticity and autocorrelation and are clustered by state of incorporation, year. ${ }^{* \star *},{ }^{\star *}$, and ${ }^{*}$ indicate significance at the $1 \%, 5 \%$, and $10 \%$ levels, respectively.

Dependent Variable

Panel A. Quadratic Specification

Antitakeover index

Square of antitakeover index

$\log$ (Assets)

Blockholder ownership

Industry Tobin's Q

Industry value for innovation proxy

Competition

Square of competition

Firm and year fixed effects

No. of obs.

$R^{2}$

Panel B. Piecewise Linear Specification

Antitakeover index $\times($ Index $\leq 2)$

Antitakeover index $\times($ Index $>2)$

Antitakeover index $\times($ Index $\leq 1)$

Antitakeover index $\times(1<$ Index $<4)$

Antitakeover index $\times($ Index $\geq 4)$

$\log$ (Assets)

Blockholder ownership

Industry Tobin's Q

Industry value for innovation proxy

Competition

Square of competition

Firm and year fixed effects

No. of obs.

$R^{2}$

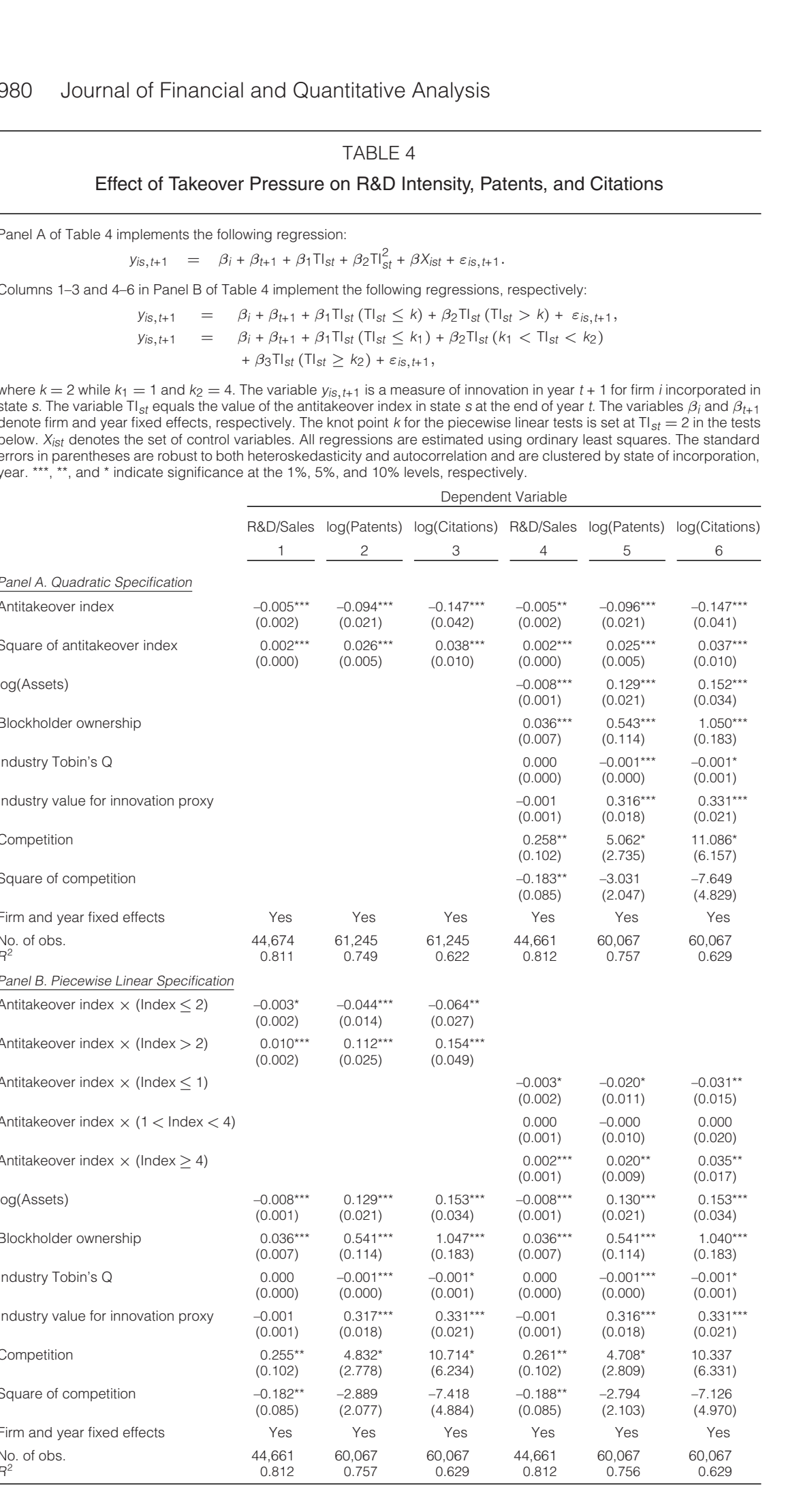


Miller (2008)). Because the logarithmic transformation accounts for outliers, we do not winsorize for patents and citations.

In columns $1-3$ in Panel A of Table $4, \beta_{1}<0$ and $\beta_{2}>0$, which is consistent with the predicted U-shaped relation. All the coefficients are statistically significant. An examination of the values of $\beta_{1}$ and $\beta_{2}$ in these specifications reveals that the value at which innovation attains its minimum, $-\beta_{1} /\left(2 \times \beta_{2}\right)$, lies in the range $0-5$ of possible values of the antitakeover index.

\section{Controlling for Other Determinants of Innovation}

We now reestimate equation (23) controlling for other time-varying determinants of firm-level innovation. Columns 4-6 in Panel A of Table 4 report the results of these tests. To control for the potential dependence of innovation on firm size, we include the logarithm of assets. We find that although firm size is negatively correlated with $\mathrm{R} \& \mathrm{D} / \mathrm{Sales}$, it is positively associated with patents and citations.

Aghion et al. (2013) show that ownership by institutional investors leads to greater innovation. Using data from CDA Spectrum, we include the percentage of shares owned by blockholders, where a blockholder is defined as anyone owning more than 5\% of the firm's shares. Consistent with Aghion et al. (2013), and the prediction of Proposition 6, we find a positive association between blockholder ownership and firm-level innovation.

Because innovation may be more likely when investment opportunities in a particular industry are greater, we include the industry Tobin's Q (calculated at the 2-digit SIC level) to control for investment/growth opportunities. ${ }^{7}$ To account for potential time-varying differences in the propensity to innovate as well as in patenting and citation practices, we include the industry-level average for the corresponding dependent variable. Consistent with the fact that patenting and citation practices vary considerably across industries, we find a strong positive association between firm-level patents and citations and the industry-level averages for these variables.

Aghion, Bloom, Blundell, Griffith, and Howitt (2005) show that innovation varies in an inverted U-shaped manner with industry-level competition. Accordingly, we include a sales-based Herfindahl measure for the 2-digit SIC industry and its square as additional controls. Like Aghion et al. (2005), we find evidence of an inverted U-shaped relation between innovation and competition, though this relation is weak in our sample.

In later tests, we show that the U-shaped relation between the degree of innovation and antitakeover laws is robust to including the GIM (2003) index as a control for firm-level antitakeover provisions. Nevertheless, it is worth mentioning that the inclusion of firm-level endogenous variables such as firm-level antitakeover provisions (as well as other endogenous variables such as managerial compensation contracts and capital structure) as additional controls could create "endogeneity" problems in our empirical analysis by distorting coefficient

\footnotetext{
${ }^{7}$ Although our results are unchanged if we instead use Tobin's Q for each firm, firm-level Q is likely to be endogenously determined along with firm-level innovation. We therefore employ industrylevel Q.
} 
estimates and standard errors of the exogenous variables. Moreover, recall that our theoretical prediction of the U-shaped relation between innovation and takeover pressure already incorporates the fact that the manager's compensation contract responds optimally to the takeover pressure she faces. Furthermore, as discussed in Section V.C, the manager's contract can be implemented in different ways through combinations of financial securities and additional payoffs contingent on a takeover. Hence, the predicted U-shaped relation also reflects the possibility that the firm could alter its financial structure and takeover provisions in response to changes in the takeover pressure to implement the optimal payoffs of agents as described by Proposition 4. Consequently, we exclude endogenously determined firm-level variables in our main set of tests. We control for firm-level antitakeover provisions in additional robustness tests.

\section{Piecewise Linear Specifications}

Next, we examine the robustness of the U-shaped relation by employing the following piecewise linear specifications:

$$
y_{i s, t+1}=\beta_{i}+\beta_{t+1}+\beta_{1} \mathrm{TI}_{s t}\left(\mathrm{TI}_{s t} \leq k\right)+\beta_{2} \mathrm{TI}_{s t}\left(\mathrm{TI}_{s t}>k\right)+\varepsilon_{i s, t+1},
$$

where $k$ denotes the knot point used for constructing the piecewise linear spline. The predicted U-shaped relation implies that the slope of the relation between innovation and the antitakeover index should be negative for low values of the index and positive for high values of the index. Thus, we predict that $\beta_{1}<0$ and $\beta_{2}>0$.

Columns 1-3 in Panel B of Table 4 report the results of estimating equation (24) where we set the knot point at $\mathrm{TI}_{s t}=2$. Across columns $1-3$, we find that $\beta_{1}<0$ and $\beta_{2}>0$, which confirms the presence of the U-shaped relation between the antitakeover index and innovation.

Next, we test for the U-shaped relation using piecewise linear specifications with two knot points as follows:

$$
\begin{aligned}
y_{i s, t+1}= & \beta_{i}+\beta_{t+1}+\beta_{1} \mathrm{TI}_{s t}\left(\mathrm{TI}_{s t} \leq k_{1}\right)+\beta_{2} \mathrm{TI}_{s t}\left(k_{1}<\mathrm{TI}_{s t}<k_{2}\right) \\
& +\beta_{3} \mathrm{TI}_{s t}\left(\mathrm{TI}_{s t} \geq k_{2}\right)+\varepsilon_{i s, t+1} .
\end{aligned}
$$

We predict that $\beta_{1}<0$ and $\beta_{3}>0$. Columns $4-6$ in Panel B of Table 4 show the results of our tests, where we set $k_{1}=1$ and $k_{2}=4$. Across the columns, we find that $\beta_{1}<0$ and $\beta_{3}>0$, which are statistically significant. Furthermore, we notice that $\beta_{2}$ is statistically indistinguishable from 0 , which provides additional support for the posited U-shaped relation.

\section{Economic Significance}

Using the coefficients in columns 1-3 of Table 4, we find that when the value of the index in a state is 0 (4), as it is in Delaware (Indiana), a 1-point increase in the value of the index decreases (increases) annual $\mathrm{R} \& \mathrm{D} / \mathrm{Sales}$ by $4.0 \%(12.0 \%)$ of the mean R\&D/Sales and annual patents and citations by $8.7 \%$ and $14.9 \%$ (11.5\% and $19.1 \%)$, respectively. Thus, we find strong evidence of an economically significant U-shaped relation between innovation and the level of the antitakeover index. 


\section{Patents and Citations per Dollar of R\&D}

Changes in takeover pressure may affect innovation at both the intrinsic and extrinsic margins; that is, they may affect not only the inputs (R\&D) and outputs (patents and citations) but the efficiency of innovation as well. We examine the potential effects of antitakeover laws on the efficiency of innovation by reestimating equations (23) and (24) using patents and citations per dollar of R\&D as the dependent variables. Table 5 reports the results of these tests. Across columns $1-6$, we find evidence of the U-shaped relation for patents and citations per dollar of R\&D investment. Therefore, we find that the passage of antitakeover laws affected not only the input and output of innovation but also the efficiency of firm-level innovation.

TABLE 5

Effect of Takeover Pressure on Patents and Citations per Dollar of R\&D

Columns 1-4 and 5-6 of Table 5 implement the following regressions, respectively:

$$
\begin{aligned}
y_{i s, t+1} & =\beta_{i}+\beta_{t+1}+\beta_{1} \mathrm{TI}_{s t}+\beta_{2} \mathrm{TI}_{s t}^{2}+\beta X_{i s t}+\varepsilon_{i s, t+1}, \\
y_{i s, t+1} & =\beta_{i}+\beta_{t+1}+\beta_{1} \mathrm{TI}_{s t}\left(\mathrm{TI}_{s t} \leq k\right)+\beta_{2} \mathrm{TI}_{s t}\left(\mathrm{TI}_{s t}>k\right)+\varepsilon_{i s, t+1} .
\end{aligned}
$$

The variable $y_{i s, t+1}$ is a measure of innovation in year $t+1$ for firm $i$ incorporated in state $s$. The variable $\mathrm{TI}_{s t}$ equals the value of the antitakeover index in state $s$ at the end of year $t$. The variables $\beta_{i}$ and $\beta_{t+1}$ denote firm and year fixed effects, respectively. The knot point $k$ for the piecewise linear tests is set at $\mathrm{Tl}_{s t}=2$ in the tests below. $X_{i s t}$ denotes the set of control variables. All regressions are estimated using ordinary least squares. The standard errors in parentheses are robust to both heteroskedasticity and autocorrelation and are clustered by state of incorporation, year. ${ }^{\star \star *}$ and ${ }^{\star *}$ indicate significance at the $1 \%$ and $5 \%$ levels, respectively.

Antitakeover index

Square of antitakeover index

Antitakeover index $\times($ Index $\leq 2)$

Antitakeover index $\times($ Index $>2)$

$\log$ (Assets)

Blockholder ownership

Industry Tobin's Q

Industry value for innovation proxy

Competition

Square of competition

Firm and year fixed effects

No. of obs.

\begin{tabular}{|c|c|c|c|c|c|}
\hline \multicolumn{6}{|c|}{ Dependent Variable } \\
\hline 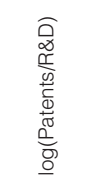 & 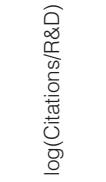 & 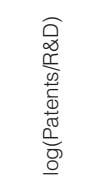 & 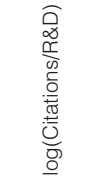 & 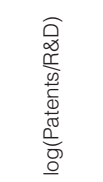 & 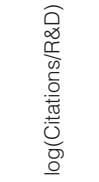 \\
\hline 1 & 2 & 3 & 4 & 5 & 6 \\
\hline $\begin{array}{l}-0.069^{\star * \star} \\
(0.016)\end{array}$ & 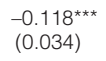 & $\begin{array}{l}-0.068^{* * *} \\
(0.016)\end{array}$ & $\begin{array}{c}-0.115^{\star \star \star} \\
(0.033)\end{array}$ & & \\
\hline \multirow[t]{9}{*}{$\begin{array}{l}0.020^{\star \star \star} \\
(0.004)\end{array}$} & $\begin{array}{l}0.032^{\star \star \star} \\
(0.008)\end{array}$ & $\begin{array}{l}0.021^{\star \star \star} \\
(0.004)\end{array}$ & $\begin{array}{l}0.033^{\star * \star} \\
(0.008)\end{array}$ & & \\
\hline & & & & $\begin{array}{c}-0.026^{\star *} \\
(0.010)\end{array}$ & $\begin{array}{c}-0.046^{\star \star} \\
(0.022)\end{array}$ \\
\hline & & & & $\begin{array}{l}0.095^{\star \star \star} \\
(0.021)\end{array}$ & $\begin{array}{l}0.146^{\star \star \star} \\
(0.039)\end{array}$ \\
\hline & & $\begin{array}{l}-0.068^{\star \star \star} \\
(0.011)\end{array}$ & $\begin{array}{l}-0.140^{\star \star *} \\
(0.024)\end{array}$ & $\begin{array}{c}-0.068^{\star \star \star} \\
(0.011)\end{array}$ & $\begin{array}{l}-0.140^{\star \star \star} \\
(0.024)\end{array}$ \\
\hline & & $\begin{array}{l}0.156^{* \star \star} \\
(0.055)\end{array}$ & $\begin{array}{l}0.506^{\star \star *} \\
(0.118)\end{array}$ & $\begin{array}{l}0.155^{\text {** }} \\
(0.055)\end{array}$ & $\begin{array}{l}0.504^{* * *} \\
(0.118)\end{array}$ \\
\hline & & $\begin{array}{c}0.001 \\
(0.001)\end{array}$ & $\begin{array}{c}0.000 \\
(0.001)\end{array}$ & $\begin{array}{c}0.001 \\
(0.001)\end{array}$ & $\begin{array}{c}0.000 \\
(0.001)\end{array}$ \\
\hline & & $\begin{array}{l}0.092^{* * *} \\
(0.028)\end{array}$ & 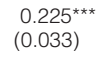 & $\begin{array}{l}0.091^{\text {***}} \\
(0.028)\end{array}$ & $\begin{array}{l}0.225^{\star \star \star} \\
(0.033)\end{array}$ \\
\hline & & $\begin{array}{l}-2.457 \\
(3.915)\end{array}$ & $\begin{array}{c}-0.675 \\
(6.790)\end{array}$ & $\begin{array}{c}-2.415 \\
(3.926)\end{array}$ & $\begin{array}{c}-0.615 \\
(6.810)\end{array}$ \\
\hline & & $\begin{array}{c}5.884 \\
(3.854)\end{array}$ & $\begin{array}{c}6.692 \\
(6.462)\end{array}$ & $\begin{array}{c}5.837 \\
(3.860)\end{array}$ & $\begin{array}{c}6.623 \\
(6.469)\end{array}$ \\
\hline Yes & Yes & Yes & Yes & Yes & Yes \\
\hline $\begin{array}{r}45,502 \\
0.484\end{array}$ & $\begin{array}{r}45,502 \\
0.419\end{array}$ & $\begin{array}{r}45,502 \\
0.486\end{array}$ & $\begin{array}{r}45,502 \\
0.423\end{array}$ & $\begin{array}{r}45,502 \\
0.485\end{array}$ & $\begin{array}{r}45,502 \\
0.422\end{array}$ \\
\hline
\end{tabular}
$R^{2}$ 


\section{Division/Subsidiary-Level Tests: Isolating the Pure Effects of Antitakeover Law Passages}

If unobserved factors leading to antitakeover law passages are correlated with our firm-level innovation measures, our preceding tests could lead to biased estimates. We now exploit a unique feature of our data to further account for the effects of unobserved state-specific factors that accompany the passage of antitakeover laws. The NBER patents data set records the location where a particular patent is filed. Using hand-collected information about the corporate family from Standard \& Poor's (S\&P) Directory of Corporate Affiliations, we identify the subsidiary/division of a firm that filed the patent in that location.

To understand our tests, consider the example of Xerox, which is headquartered and incorporated in Rochester, NY. However, its research labs are located in Rochester, NY, as well as in Palo Alto, CA. Using our hand-collected data, we can distinguish between patents filed by the Palo Alto Research Center and the Rochester laboratories. Antitakeover laws passed by New York would be expected to affect innovation at both its Palo Alto Research Center and its Rochester laboratories. However, any statewide economic changes accompanying the law passage in New York are unlikely to affect innovation at the Palo Alto Research Center.

The above example illustrates that we can potentially isolate the pure effect of the antitakeover law passage on innovation by examining the impact on innovation in divisions/subsidiaries located outside the state of incorporation. For firms whose headquarter state and the state of incorporation differ from each other, we also exclude patents filed in the headquarter state. In many instances, firms assign their patents to the division/subsidiary that made the innovation. In fact, we have more than 50,000 observations at the division/subsidiary-year level for such patents. It is this variation that we exploit in the test below:

$$
y_{k i s, t+1}=\beta_{k}+\beta_{t+1}+\beta_{1} \mathrm{TI}_{s t}+\beta_{2} \mathrm{TI}_{s t}^{2}+\beta X_{i s t}+\varepsilon_{k i s, t+1},
$$

where $y_{k i s, t}$ denotes the innovation in year $t$ for subsidiary/division $k$ of firm $i$. Firm $i$ is incorporated in state $s$, but the subsidiary/division $k$ is located outside state $s$ and the firm's headquarter state. $\beta_{k}$ denotes fixed effects corresponding to subsidiary/division $k$ filing the patent; because the subsidiary/division's state location does not vary with time, $\beta_{k}$ subsumes fixed effects for the state in which the subsidiary/division is located. Thus, by controlling for average unobserved determinants of innovation at the subsidiary/division level and for time trends through the year fixed effects $\beta_{t+1}$, we identify the predicted effect using variation caused by the antitakeover law change in state $s$. The other variables are defined similarly as in equation (23).

Table 6 reports the results of the tests. Because subsidiary-level information is not available for R\&D intensity, we test only for patents and citations. The specifications employed for these are identical to those for patents and citations in Table 4 . We note that $\beta_{1}<0$ and $\beta_{2}>0$, which is consistent with the predicted U-shaped relation; all the coefficients are statistically significant. 
TABLE 6

Effect of Takeover Pressure on Innovation Using Patents Filed by Subsidiaries/Divisions Outside the State of Incorporation and State of Firm Headquarters

Columns $1-4$ and 5-6 of Table 6 implement the following regressions, respectively:

$$
\begin{aligned}
& y_{k i s, t+1}=\beta_{i}+\beta_{t+1}+\beta_{1} \mathrm{Tl}_{s t}+\beta_{2} \mathrm{TI}_{s t}^{2}+\beta X_{i s t}+\varepsilon_{k i s, t+1}, \\
& y_{k i s, t+1}=\beta_{i}+\beta_{t+1}+\beta_{1} \mathrm{Tl}_{s t}\left(\mathrm{Tl}_{s t} \leq k\right)+\beta_{2} \mathrm{TI}_{s t}\left(\mathrm{TI}_{s t}>k\right)+\varepsilon_{k i s, t+1} .
\end{aligned}
$$

The variable $y_{k i s, t+1}$ is a measure of innovation in year $t+1$ for division/subsidiary $k$ of firm $i$ incorporated in state $s$. The variable $\mathrm{Tl}_{s t}$ equals the value of the antitakeover index in state $s$ at the end of year $t$. The variables $\boldsymbol{\beta}_{i}$ and $\boldsymbol{\beta}_{t+1}$ denote firm and year fixed effects, respectively. The knot point $k$ for the piecewise linear tests is set at $\mathrm{TI}_{s t}=2$ in the tests below. $X_{\text {ist }}$ denotes the set of control variables. All regressions are estimated using ordinary least squares. The standard errors in parentheses are robust to both heteroskedasticity and autocorrelation and are clustered by state of incorporation, year. ${ }^{* * *}$ and ${ }^{* \star}$ indicate significance at the $1 \%$ and $5 \%$ levels, respectively.

\begin{tabular}{|c|c|c|c|c|c|c|}
\hline & \multicolumn{6}{|c|}{ Dependent vanable } \\
\hline & $\log$ (Patents) & $\log ($ Citations) & $\log$ (Patents) & $\log ($ Citations $)$ & $\log$ (Patents) & $\log ($ Citations $)$ \\
\hline & 1 & 2 & 3 & 4 & 5 & 6 \\
\hline Antitakeover index & $\begin{array}{l}-0.092^{\star \star *} \\
(0.023)\end{array}$ & 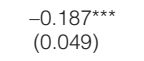 & $\begin{array}{l}-0.092^{* * *} \\
(0.022)\end{array}$ & $\begin{array}{l}-0.184^{\star \star \star} \\
(0.047)\end{array}$ & & \\
\hline Square of antitakeover index & $\begin{array}{l}0.030^{\star \star \star} \\
(0.005)\end{array}$ & $\begin{array}{l}0.059^{\star \star \star} \\
(0.011)\end{array}$ & $\begin{array}{l}0.029^{\star \star \star} \\
(0.005)\end{array}$ & $\begin{array}{l}0.056^{\star \star \star} \\
(0.010)\end{array}$ & & \\
\hline Antitakeover index $\times($ Index $\leq 1)$ & & & & & $\begin{array}{l}-0.075^{\star \star \star} \\
(0.020)\end{array}$ & $\begin{array}{l}-0.145^{\text {*** }} \\
(0.042)\end{array}$ \\
\hline Antitakeover index $\times($ Index $>1)$ & & & & & $\begin{array}{l}0.165^{\text {***}} \\
(0.029)\end{array}$ & 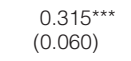 \\
\hline $\log ($ Assets) & & & $\begin{array}{l}0.067^{\star \star \star} \\
(0.014)\end{array}$ & $\begin{array}{l}0.103^{\star \star \star} \\
(0.024)\end{array}$ & $\begin{array}{l}0.066^{\star \star \star} \\
(0.014)\end{array}$ & $\begin{array}{l}0.102^{\star \star \star} \\
(0.024)\end{array}$ \\
\hline Blockholder ownership & & & $\begin{array}{c}0.145^{* *} \\
(0.066)\end{array}$ & $\begin{array}{l}0.315^{\star \star} \\
(0.123)\end{array}$ & $\begin{array}{l}0.150^{* *} \\
(0.065)\end{array}$ & $\begin{array}{l}0.325^{\star \star \star} \\
(0.122)\end{array}$ \\
\hline Industry Tobin's Q & & & $\begin{array}{c}-0.000 \\
(0.000)\end{array}$ & $\begin{array}{c}-0.001 \\
(0.001)\end{array}$ & $\begin{array}{c}-0.000 \\
(0.000)\end{array}$ & $\begin{array}{c}-0.001 \\
(0.001)\end{array}$ \\
\hline Industry value for innovation proxy & & & $\begin{array}{l}0.170^{* * *} \\
(0.028)\end{array}$ & $\begin{array}{l}0.281^{\star \star \star} \\
(0.052)\end{array}$ & $\begin{array}{l}0.172^{\star \star \star} \\
(0.028)\end{array}$ & $\begin{array}{l}0.284^{\text {*** }} \\
(0.052)\end{array}$ \\
\hline Competition & & & $\begin{array}{c}1.031 \\
(2.356)\end{array}$ & $\begin{array}{c}-2.589 \\
(6.108)\end{array}$ & $\begin{array}{c}0.848 \\
(2.408)\end{array}$ & $\begin{array}{c}-2.964 \\
(6.214)\end{array}$ \\
\hline Square of competition & & & $\begin{array}{c}0.611 \\
(2.016)\end{array}$ & $\begin{array}{c}5.477 \\
(5.124)\end{array}$ & $\begin{array}{c}0.768 \\
(2.051)\end{array}$ & $\begin{array}{c}5.795 \\
(5.195)\end{array}$ \\
\hline $\begin{array}{l}\text { Subsidiary/division fixed effects } \\
\text { Firm and year fixed effects }\end{array}$ & $\begin{array}{l}\text { Yes } \\
\text { Yes }\end{array}$ & $\begin{array}{l}\text { Yes } \\
\text { Yes }\end{array}$ & $\begin{array}{l}\text { Yes } \\
\text { Yes }\end{array}$ & $\begin{array}{l}\text { Yes } \\
\text { Yes }\end{array}$ & $\begin{array}{l}\text { Yes } \\
\text { Yes }\end{array}$ & $\begin{array}{l}\text { Yes } \\
\text { Yes }\end{array}$ \\
\hline $\begin{array}{l}\text { No. of obs. } \\
R^{2}\end{array}$ & $\begin{array}{r}51,582 \\
0.686\end{array}$ & $\begin{array}{r}51,582 \\
0.559\end{array}$ & $\begin{array}{r}50,475 \\
0.689\end{array}$ & $\begin{array}{r}50,475 \\
0.559\end{array}$ & $\begin{array}{r}50,475 \\
0.688\end{array}$ & $\begin{array}{r}50,475 \\
0.558\end{array}$ \\
\hline
\end{tabular}

Dependent Variable

\section{Additional Tests Accounting for Endogeneity of Antitakeover Law Passages}

We now conduct a series of tests to mitigate concerns of endogeneity in our original tests in Table 4.

\section{Panel Regressions with State-Specific Time Trends}

To examine whether other state-level changes accompanying the antitakeover law passages affect our results, we incorporate state-specific time trends as in Besley and Burgess (2004):

$$
y_{i s, t+1}=\beta_{i}+\beta_{t+1}+(t+1) \beta_{s}+\beta_{1} \mathrm{TI}_{s t}+\beta_{2} \mathrm{TI}_{s t}^{2}+\beta X_{i s t}+\varepsilon_{i s, t+1} .
$$


In equation (26), $(t+1) \beta_{s}$ represent time trends that are specific to each state of incorporation. The other variables are as defined in equation (23). By accounting for these state-specific time trends, we identify the predicted effects using deviations (at the firm level) from the average time trend for each state of incorporation. Because other state-level changes accompanying the antitakeover law passages could lead to state-specific time trends, these tests are designed to better isolate the pure effect of antitakeover law passages on innovation. As Angrist and Pischke (2009) describe, difference-in-difference estimations require the identifying assumption that the counterfactual trends in the treatment and control groups are the same. Inclusion of a time trend for each state accommodates the possibility that pre- and post-trends in innovation may differ across the treatment and control groups.

Columns 1-3 of Table 7 show the results of these tests. Across the columns, $\beta_{1}<0$ and $\beta_{2}>0$, which is consistent with the predicted $\mathrm{U}$-shaped relation.

\section{TABLE 7}

Effect of Takeover Pressure on Innovation After Accounting for Endogeneity of Antitakeover Law Passages

Columns $1-3$ of Table 7 below implement the regression:

$$
y_{i s, t+1}=\beta_{i}+\beta_{t+1}+(t+1) \beta_{S}+(t+1) \beta_{S I C}+\beta_{1} \mathrm{Tl}_{s t}+\beta_{2} \mathrm{Tl}_{s t}^{2}+\beta X_{i s t}+\varepsilon_{\text {is }, t+1} .
$$

Columns 4-6 do not include state-of-incorporation-specific trends $(t+1) \beta_{S}$, and columns 7-9 include state-of-incorporationspecific trends $(t+1) \beta_{s}$ and industry-specific trends $(t+1) \beta_{\mathrm{SIC} 2}$. The variable $y_{\text {is, } t+1}$ is a measure of innovation in year $t+1$ for firm $i$ incorporated in state $s$. The variable $\mathrm{Tl}_{s t}$ equals the value of the antitakeover index in state $s$ at the end of year $t$. The variables $\beta_{i}$ and $\beta_{t+1}$ denote firm and year fixed effects, respectively. $X_{i s t}$ denotes the set of control variables. All regressions are estimated using ordinary least squares. The standard errors in parentheses are robust to both heteroskedasticity and autocorrelation and are clustered by state of incorporation, year. ${ }^{\star \star *},{ }^{\star \star}$, and * indicate significance at the $1 \%, 5 \%$, and $10 \%$ levels, respectively.

Dependent Variable

\begin{tabular}{|c|c|c|c|c|c|c|c|c|c|}
\hline & $\begin{array}{l}\frac{\infty}{\infty} \\
\frac{\infty}{\mathscr{D}} \\
\stackrel{D}{\infty} \\
\simeq\end{array}$ & $\begin{array}{l}\widehat{D} \\
\stackrel{0}{0} \\
\frac{0}{\sigma} \\
\stackrel{0}{0} \\
\text { O }\end{array}$ & 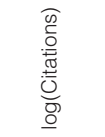 & $\begin{array}{l}\frac{\mathscr{d}}{\pi} \\
\mathscr{D} \\
\stackrel{D}{\mathscr{D}} \\
\simeq\end{array}$ & 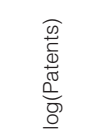 & 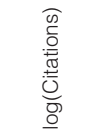 & $\begin{array}{l}\mathscr{\infty} \\
\frac{\mathcal{D}}{\widetilde{N}} \\
\stackrel{\mathscr{D}}{D} \\
\not{\alpha} \\
\simeq\end{array}$ & 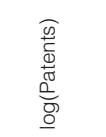 & 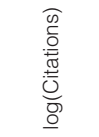 \\
\hline & 1 & 2 & 3 & 4 & 5 & 6 & 7 & 8 & 9 \\
\hline Antitakeover index & $\begin{array}{l}-0.004^{\star \star} \\
(0.002)\end{array}$ & $\begin{array}{l}-0.058^{* * *} \\
(0.017)\end{array}$ & $\begin{array}{l}-0.082^{\star \star} \\
(0.036)\end{array}$ & $\begin{array}{l}-0.004^{\star \star} \\
(0.002)\end{array}$ & $\begin{array}{l}-0.050^{\star \star \star} \\
(0.017)\end{array}$ & $\begin{array}{l}-0.095^{\star * *} \\
(0.036)\end{array}$ & $\begin{array}{l}-0.004^{\star \star} \\
(0.002)\end{array}$ & $\begin{array}{l}-0.058^{\star \star \star} \\
(0.017)\end{array}$ & $\begin{array}{l}-0.081^{\star \star} \\
(0.036)\end{array}$ \\
\hline $\begin{array}{l}\text { Square of } \\
\text { antitakeover index }\end{array}$ & $\begin{array}{l}0.001^{* *} \\
(0.000)\end{array}$ & $\begin{array}{l}0.015^{\star \star \star} \\
(0.005)\end{array}$ & $\begin{array}{l}0.022^{\star \star} \\
(0.010)\end{array}$ & $\begin{array}{l}0.001^{\star * *} \\
(0.000)\end{array}$ & $\begin{array}{l}0.014^{* * *} \\
(0.005)\end{array}$ & $\begin{array}{l}0.026^{\star \star \star} \\
(0.009)\end{array}$ & $\begin{array}{l}0.001^{\star \star} \\
(0.000)\end{array}$ & $\begin{array}{l}0.015^{\star \star \star} \\
(0.005)\end{array}$ & $\begin{array}{l}0.022^{\star *} \\
(0.010)\end{array}$ \\
\hline $\log$ (Assets) & $\begin{array}{l}-0.008^{* * *} \\
(0.001)\end{array}$ & $\begin{array}{l}0.129^{\star \star \star} \\
(0.021)\end{array}$ & $\begin{array}{l}0.150^{\star \star \star} \\
(0.034)\end{array}$ & $\begin{array}{l}-0.008^{* \star *} \\
(0.001)\end{array}$ & $\begin{array}{l}0.129^{* * *} \\
(0.021)\end{array}$ & $\begin{array}{l}0.153^{\star \star \star} \\
(0.034)\end{array}$ & $\begin{array}{l}-0.008^{\star \star \star} \\
(0.002)\end{array}$ & $\begin{array}{l}0.128^{\star \star \star} \\
(0.021)\end{array}$ & $\begin{array}{l}0.150^{\star \star *} \\
(0.034)\end{array}$ \\
\hline $\begin{array}{l}\text { Blockholder } \\
\text { ownership }\end{array}$ & $\begin{array}{l}0.034^{\star * \star} \\
(0.007)\end{array}$ & $\begin{array}{l}0.516^{\star \star \star} \\
(0.119)\end{array}$ & $\begin{array}{l}0.968^{\star \star \star} \\
(0.190)\end{array}$ & $\begin{array}{l}0.034^{\star \star \star} \\
(0.007)\end{array}$ & $\begin{array}{l}0.515^{\star \star \star} \\
(0.119)\end{array}$ & $\begin{array}{l}0.980^{\star \star \star} \\
(0.192)\end{array}$ & $\begin{array}{l}0.038^{\star \star \star} \\
(0.007)\end{array}$ & $\begin{array}{l}0.542^{\star \star \star} \\
(0.122)\end{array}$ & $\begin{array}{l}1.035^{\star \star \star} \\
(0.196)\end{array}$ \\
\hline Industry Tobin's Q & $\begin{array}{c}0.000 \\
(0.000)\end{array}$ & $\begin{array}{l}-0.001^{\text {** }} \\
(0.000)\end{array}$ & $\begin{array}{l}-0.002^{\star \star \star} \\
(0.001)\end{array}$ & $\begin{array}{c}0.000 \\
(0.000)\end{array}$ & $\begin{array}{l}-0.001^{* * *} \\
(0.000)\end{array}$ & $\begin{array}{l}-0.001^{* *} \\
(0.001)\end{array}$ & $\begin{array}{c}0.000 \\
(0.000)\end{array}$ & $\begin{array}{l}-0.000 \\
(0.000)\end{array}$ & $\begin{array}{l}-0.001 \\
(0.001)\end{array}$ \\
\hline Competition & $\begin{array}{l}0.223^{* *} \\
(0.101)\end{array}$ & $\begin{array}{c}3.957 \\
(2.966)\end{array}$ & $\begin{array}{c}3.835 \\
(6.865)\end{array}$ & $\begin{array}{l}0.230^{* *} \\
(0.100)\end{array}$ & $\begin{array}{c}4.170 \\
(2.908)\end{array}$ & $\begin{array}{c}9.339 \\
(6.596)\end{array}$ & $\begin{array}{c}0.173 \\
(0.181)\end{array}$ & $\begin{array}{c}2.641 \\
(2.886)\end{array}$ & $\begin{array}{c}6.266 \\
(7.126)\end{array}$ \\
\hline $\begin{array}{l}\text { Square of } \\
\text { competition }\end{array}$ & $\begin{array}{l}-0.164^{*} \\
(0.084)\end{array}$ & $\begin{array}{l}-2.018 \\
(2.283)\end{array}$ & $\begin{array}{l}-1.007 \\
(5.455)\end{array}$ & $\begin{array}{l}-0.166^{\star \star} \\
(0.083)\end{array}$ & $\begin{array}{l}-2.216 \\
(2.219)\end{array}$ & $\begin{array}{l}-6.085 \\
(5.295)\end{array}$ & $\begin{array}{l}-0.117 \\
(0.139)\end{array}$ & $\begin{array}{l}-1.087 \\
(2.429)\end{array}$ & $\begin{array}{l}-3.260 \\
(6.331)\end{array}$ \\
\hline $\begin{array}{l}\text { Industry value for } \\
\text { innovation proxy }\end{array}$ & $\begin{array}{l}-0.001 \\
(0.001)\end{array}$ & $\begin{array}{l}0.310^{\star \star \star} \\
(0.019)\end{array}$ & $\begin{array}{l}0.558^{\star \star \star} \\
(0.045)\end{array}$ & $\begin{array}{l}-0.001 \\
(0.001)\end{array}$ & $\begin{array}{l}0.309^{* * *} \\
(0.019)\end{array}$ & $\begin{array}{l}0.324^{* \star *} \\
(0.021)\end{array}$ & $\begin{array}{l}-0.000 \\
(0.001)\end{array}$ & $\begin{array}{l}0.281^{\star \star \star} \\
(0.021)\end{array}$ & $\begin{array}{l}0.349^{* * *} \\
(0.018)\end{array}$ \\
\hline $\begin{array}{l}\text { Min. innovation } \\
\text { proxy for } \\
\text { incorporated state }\end{array}$ & & & & $\begin{array}{c}0.147 \\
(0.536)\end{array}$ & $\begin{array}{l}0.557^{\star \star \star} \\
(0.114)\end{array}$ & $\begin{array}{l}0.596^{\star \star \star} \\
(0.065)\end{array}$ & & & \\
\hline $\begin{array}{l}\text { Max. innovation } \\
\text { proxy for }\end{array}$ & & & & $\begin{array}{l}0.032^{* \star \star} \\
(0.005)\end{array}$ & $\begin{array}{l}0.072^{\star \star \star} \\
(0.013)\end{array}$ & $\begin{array}{l}0.115^{\star \star \star} \\
(0.019)\end{array}$ & & & \\
\hline
\end{tabular}


TABLE 7 (continued)

Effect of Takeover Pressure on Innovation After Accounting for Endogeneity of Antitakeover Law Passages

\begin{tabular}{|c|c|c|c|c|c|c|c|c|c|}
\hline & \multicolumn{9}{|c|}{ Dependent Variable } \\
\hline & 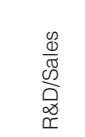 & 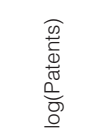 & 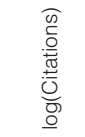 & $\begin{array}{l}\infty \\
\frac{\infty}{\tilde{N}} \\
\tilde{D} \\
\tilde{D} \\
\approx \\
\widetilde{\Sigma}\end{array}$ & 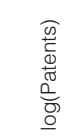 & 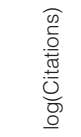 & 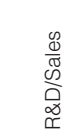 & 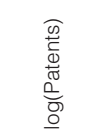 & 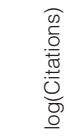 \\
\hline & 1 & 2 & 3 & 4 & 5 & 6 & 7 & 8 & 9 \\
\hline $\begin{array}{l}\text { Firm and year fixed } \\
\text { effects }\end{array}$ & Yes & Yes & Yes & Yes & Yes & Yes & Yes & Yes & Yes \\
\hline $\begin{array}{l}\text { State-of- } \\
\text { incorporation- } \\
\text { specific trends }\end{array}$ & Yes & Yes & Yes & No & No & No & Yes & Yes & Yes \\
\hline $\begin{array}{l}\text { Industry-specific } \\
\text { trends }\end{array}$ & No & No & No & No & No & No & Yes & Yes & Yes \\
\hline $\begin{array}{l}\text { No. of obs. } \\
R^{2}\end{array}$ & $\begin{array}{r}44,661 \\
0.813\end{array}$ & $\begin{array}{r}60,067 \\
0.759\end{array}$ & $\begin{array}{r}60,067 \\
0.631\end{array}$ & $\begin{array}{r}44,661 \\
0.813\end{array}$ & $\begin{array}{r}60,067 \\
0.759\end{array}$ & $\begin{array}{r}60,067 \\
0.632\end{array}$ & $\begin{array}{r}44,661 \\
0.815\end{array}$ & $\begin{array}{r}60,067 \\
0.761\end{array}$ & $\begin{array}{r}60,067 \\
0.634\end{array}$ \\
\hline
\end{tabular}

\section{Effect of Firm-Level Innovation Outcomes Before the Law Passages}

Antitakeover law passages may have been triggered by the innovation outcomes of a few influential firms incorporated in a particular state. It is possible that the state legislatures passed the antitakeover laws in response to the innovation outcomes of these firms, which could imply a reverse causal relation. Because the above would lead to a state-specific time trend, the earlier tests partially account for this possibility. Although we investigate further a potential reverse causal relation in Section V.E, here we address this concern by including the maximum and minimum levels of innovation among firms incorporated in a particular state as additional control variables:

$$
\begin{aligned}
y_{i s, t+1}= & \beta_{i}+\beta_{t+1}+\beta_{1} \mathrm{TI}_{s t}+\beta_{2} \mathrm{TI}_{s t}^{2}+\beta_{3} \min \left(\mathrm{INNOVN}_{s t}\right) \\
& +\beta_{4} \max \left(\mathrm{INNOVN}_{s t}\right)+\beta X_{i s t}+\varepsilon_{i s, t+1} .
\end{aligned}
$$

In the above, $\min \left(\operatorname{INNOVN}_{s t}\right)$ and $\max \left(\operatorname{INNOVN}_{s t}\right)$ denote the minimum and maximum levels of innovation among firms incorporated in state $s$ at time $t$. These variables account for the possibility that the legislature in state $s$ passed the antitakeover law at time $t$ because of an event at time $t$ specific to the most/least innovative firm incorporated in that state.

Columns 4-6 of Table 7 show the results of regression (27). We find that the coefficients $\beta_{3}$ and $\beta_{4}$ are both positive. Crucially, however, we find that the $\mathrm{U}$-shaped relation between innovation and takeover pressure continues to be as strong as before.

\section{Unidirectional Nature of the Antitakeover Law Passages}

As shown by Figure 1 and Table 1, all the states enacted laws that reduced the takeover pressure faced by firms incorporated in these states. This unidirectional nature of antitakeover law changes raises an important concern that the preceding results are potentially affected by a positive time trend in innovation combined 
with the secular decreases in antitakeover pressure. Such a positive time trend may result, for example, because of the technological breakthroughs in the late 1980s and early 1990s. The trend may also be related to the creation of the CAFC by Congress in 1982, whose main jurisdiction relates to appeals made regarding U.S. patent law. Following the creation of the CAFC, there was a large surge in patenting in the United States. Kortum and Lerner (1999) attribute this surge in patenting to factors such as changes in the management of research following the creation of the CAFC. Our next set of tests is designed to examine whether our results are affected by the surge in patenting activity, which overlaps with the period the antitakeover laws were passed.

It is worth mentioning that our preceding tests do alleviate such concerns. First, we find a U-shaped relation for R\&D/Sales, which was largely unaffected by the surge in patenting activity (Kortum and Lerner (1999)). We find a similar U-shaped relation between the efficiency of innovation and takeover pressure in Table 5. Second, our year fixed effects control for any average increase in patenting activity across all states and, in turn, all firms. Third, the state-specific time trends included in our tests in Section V.D.1 account for the possibility that the surge in patenting activity due to the creation of the CAFC manifested differently in different states.

Nevertheless, it is possible that the time trends in innovation manifested differently across different industries. To address such concerns, we include industryand state-specific time trends in the following specification:

$$
\begin{aligned}
y_{i s, t+1}= & \beta_{i}+\beta_{t+1}+(t+1) \beta_{s}+(t+1) \beta_{\mathrm{SIC} 2}+\beta_{1} \mathrm{TI}_{s t} \\
& +\beta_{2} \mathrm{TI}_{s t}^{2}+\beta X_{i s t}+\varepsilon_{i s, t+1},
\end{aligned}
$$

where $(t+1) \beta_{\text {SIC2 }}$ denotes the time trends specific to each 2-digit SIC industry. The other variables are as defined in equation (26). In columns 7-9 of Table 7, we find that the U-shaped relation continues to be statistically and economically significant.

\section{E. Additional Robustness Tests}

\section{Reverse Causality}

We now further investigate the possibility of a reverse causal relation between innovation and takeover pressure by examining the dynamic aspects of the effect of the law passages. We alter equation (23) by including the terms $\mathrm{TI}_{s, t+2}$ and $\mathrm{TI}_{s, t+2}^{2}$ with the terms $\mathrm{TI}_{s t}$ and $\mathrm{TI}_{s t}^{2}$ as independent variables to decompose the total effect of antitakeover laws into any potential effects before and after the passage of the laws:

$$
\begin{aligned}
y_{i s, t+1}= & \beta_{i}+\beta_{t+1}+(t+1) \beta_{s}+(t+1) \beta_{\mathrm{SIC} 2}+\beta_{1} \mathrm{TI}_{s t}+\beta_{2} \mathrm{TI}_{s t}^{2} \\
& +\beta_{3} \mathrm{TI}_{s, t+2}+\beta_{4} \mathrm{TI}_{s, t+2}^{2}+\varepsilon_{i s, t+1} .
\end{aligned}
$$

Note that there are multiple antitakeover law passages within a state at different points in time and we are testing for a nonlinear relation. We therefore cannot implement the variant of reverse causality tests employed by Bertrand and Mullainathan (2003), who focus on business combination laws that were enacted only once in every state. To fix ideas, consider the passage of antitakeover laws 
in Florida in 1987 and 1989. For the change in 1987, $\beta_{1}$ and $\beta_{2}$ in equation (29) capture the effect on innovation for firms incorporated in Florida (vis-à-vis the effects on innovation for firms incorporated in other states) from 1988 onward, while $\beta_{3}$ and $\beta_{4}$ capture this effect in 1986 and 1987. Similarly, for the law change in $1989, \beta_{1}$ and $\beta_{2}$ capture the effect on innovation from 1990 onward while $\beta_{3}$ and $\beta_{4}$ capture this effect in 1988 and 1989. Thus, $\beta_{3}$ and $\beta_{4}$ capture the effect of antitakeover laws on innovation in the year before as well as the year of law passage. If $\beta_{3}$ and $\beta_{4}$ are insignificant, this implies that reverse causal effects are unlikely to be present.

Columns 1-3 of Table 8 report the results of the above tests. As shown by the coefficients $\beta_{3}$ and $\beta_{4}$, there appears to be no evidence of a reverse causal

TABLE 8

Dynamic Effects of Takeover Pressure on Innovation

Table 8 implements the following regression:

$$
y_{i s, t+1}=\beta_{i}+\beta_{t+1}+(t+1) \beta_{S}+(t+1) \beta_{S I C}+\beta_{1} \mathrm{Tl}_{s t}+\beta_{2} \mathrm{Tl}_{s t}^{2}+\beta_{3} \mathrm{TI}_{s, t-2}+\beta_{4} \mathrm{TI}_{s, t-2}^{2}+\varepsilon_{i s, t+1} .
$$

The variable $y_{i s, t+1}$ is a measure of innovation in year $t+1$ for firm $i$ incorporated in state $s$. The variables $\mathrm{TI}_{S t}$, and $\mathrm{TI}_{s, t+1}$ equal the value of the antitakeover index in state $s$ at the end of years $t$ and $t+1$, respectively. The variables $\beta_{i}$ and $\beta_{t+1}$ denote firm and year fixed effects, respectively, and $(t+1) \beta_{S}$ and $(t+1) \beta_{\text {SIC2 }}$ denote state-of-incorporation-specific trends and industry-specific trends, respectively. The knot point $k$ for the piecewise linear tests is set at $\mathrm{TI}_{s t}=2$ in the tests below. $X_{i s t}$ denotes the set of control variables. All regressions are estimated using ordinary least squares. The standard errors in parentheses are robust to both heteroskedasticity and autocorrelation and are clustered by state of incorporation, year. ${ }^{* * *},{ }^{* *}$, and ${ }^{*}$ indicate significance at the $1 \%, 5 \%$, and $10 \%$ levels, respectively.

Dependent Variable

Antitakeover index

Square of antitakeover index

Antitakeover index $(t+1)$

Square of antitakeover index $(t+1)$

Antitakeover index $(t-2)$

Square of antitakeover index $(t-2)$

$\log$ (Assets)

Blockholder ownership

Industry Tobin's Q

Competition

Square of competition

Industry value for innovation proxy

Firm and year fixed effects

State-of-incorporation-specific trends Industry-specific trends

No. of obs.

$R^{2}$

\begin{tabular}{|c|c|c|c|c|c|}
\hline \multicolumn{6}{|c|}{ Dependent Variable } \\
\hline R\&D/Sales & $\log$ (Patents) & $\log ($ Citations) & R\&D/Sales & $\log$ (Patents) & $\log ($ Citations) \\
\hline 1 & 2 & 3 & 4 & 5 & 6 \\
\hline $\begin{array}{l}-0.006^{\star \star \star} \\
(0.002)\end{array}$ & $\begin{array}{c}-0.038^{\star \star \star} \\
(0.014)\end{array}$ & $\begin{array}{c}-0.043 \\
(0.033)\end{array}$ & $\begin{array}{c}-0.003^{*} \\
(0.002)\end{array}$ & $\begin{array}{c}-0.015 \\
(0.019)\end{array}$ & $\begin{array}{c}-0.000 \\
(0.041)\end{array}$ \\
\hline $\begin{array}{l}0.001^{* *} \\
(0.000)\end{array}$ & $\begin{array}{l}0.009^{\star \star} \\
(0.004)\end{array}$ & $\begin{array}{c}0.010 \\
(0.009)\end{array}$ & $\begin{array}{l}0.001^{\star \star} \\
(0.000)\end{array}$ & $\begin{array}{c}0.005 \\
(0.005)\end{array}$ & $\begin{array}{c}0.003 \\
(0.010)\end{array}$ \\
\hline $\begin{array}{c}0.001 \\
(0.002)\end{array}$ & $\begin{array}{c}-0.024^{*} \\
(0.014)\end{array}$ & $\begin{array}{c}-0.035 \\
(0.033)\end{array}$ & & & \\
\hline \multirow[t]{3}{*}{$\begin{array}{c}-0.000 \\
(0.000)\end{array}$} & $\begin{array}{c}0.004 \\
(0.003)\end{array}$ & $\begin{array}{c}0.006 \\
(0.008)\end{array}$ & & & \\
\hline & & & $\begin{array}{c}0.002 \\
(0.002)\end{array}$ & $\begin{array}{l}-0.044^{\star \star *} \\
(0.015)\end{array}$ & $\begin{array}{l}-0.091^{\text {***}} \\
(0.032)\end{array}$ \\
\hline & & & $\begin{array}{c}-0.000 \\
(0.000)\end{array}$ & $\begin{array}{l}0.017^{\star \star \star} \\
(0.005)\end{array}$ & $\begin{array}{l}0.035^{\star \star \star} \\
(0.009)\end{array}$ \\
\hline 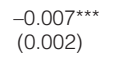 & $\begin{array}{l}0.087^{\star \star \star} \\
(0.012)\end{array}$ & $\begin{array}{l}0.094^{* * *} \\
(0.022)\end{array}$ & $\begin{array}{l}-0.006^{\star * *} \\
(0.002)\end{array}$ & $\begin{array}{l}0.142^{* \star *} \\
(0.023)\end{array}$ & $\begin{array}{l}0.183^{\star \star \star} \\
(0.035)\end{array}$ \\
\hline $\begin{array}{l}0.035^{\star \star \star} \\
(0.007)\end{array}$ & $\begin{array}{l}0.350^{\star \star \star} \\
(0.130)\end{array}$ & $\begin{array}{l}0.756^{\star \star \star} \\
(0.263)\end{array}$ & $\begin{array}{l}0.024^{\star \star \star} \\
(0.008)\end{array}$ & $\begin{array}{l}0.564^{\star \star *} \\
(0.119)\end{array}$ & $\begin{array}{l}1.040^{* \star \star} \\
(0.193)\end{array}$ \\
\hline $\begin{array}{c}0.000 \\
(0.000)\end{array}$ & $\begin{array}{c}-0.000 \\
(0.000)\end{array}$ & $\begin{array}{c}-0.001 \\
(0.001)\end{array}$ & $\begin{array}{c}0.000 \\
(0.000)\end{array}$ & $\begin{array}{c}-0.000 \\
(0.000)\end{array}$ & $\begin{array}{c}-0.001 \\
(0.001)\end{array}$ \\
\hline $\begin{array}{c}-0.004 \\
(0.177)\end{array}$ & $\begin{array}{c}0.880 \\
(2.999)\end{array}$ & $\begin{array}{c}3.797 \\
(8.232)\end{array}$ & $\begin{array}{c}-0.026 \\
(0.195)\end{array}$ & $\begin{array}{c}3.848 \\
(3.360)\end{array}$ & $\begin{array}{c}8.296 \\
(7.012)\end{array}$ \\
\hline $\begin{array}{c}-0.017 \\
(0.138)\end{array}$ & $\begin{array}{c}-0.182 \\
(2.615)\end{array}$ & $\begin{array}{c}-1.756 \\
(7.103)\end{array}$ & $\begin{array}{c}0.067 \\
(0.146)\end{array}$ & $\begin{array}{c}-2.375 \\
(3.035)\end{array}$ & $\begin{array}{c}-5.785 \\
(6.595)\end{array}$ \\
\hline $\begin{array}{c}-0.000 \\
(0.001)\end{array}$ & $\begin{array}{l}0.321^{\star \star \star} \\
(0.022)\end{array}$ & $\begin{array}{l}0.356^{\star \star \star} \\
(0.020)\end{array}$ & $\begin{array}{c}-0.001 \\
(0.001)\end{array}$ & $\begin{array}{l}0.301^{\star \star \star} \\
(0.026)\end{array}$ & $\begin{array}{l}0.357^{\star * *} \\
(0.020)\end{array}$ \\
\hline Yes & Yes & Yes & Yes & Yes & Yes \\
\hline Yes & Yes & Yes & Yes & Yes & Yes \\
\hline Yes & Yes & Yes & Yes & Yes & Yes \\
\hline 37,400 & 52,059 & 52,059 & 31,655 & 52,057 & 52,057 \\
\hline 0.820 & 0.785 & 0.654 & 0.841 & 0.773 & 0.646 \\
\hline
\end{tabular}


relation. Importantly, we continue to find that $\beta_{1}<0$ and $\beta_{2}>0$, which support the posited U-shaped relation between innovation after a law passage and takeover pressure.

\section{Long-Run Effects}

We would expect changes in takeover pressure to have short-term effects on $R \& D$ investment because they are inputs to innovation, and long-term effects on patents and citations because they are outputs. To examine the short- and long-run effects of antitakeover laws on innovation, we estimate the following specification:

$$
\begin{aligned}
y_{i s, t+1}= & \beta_{i}+\beta_{t+1}+(t+1) \beta_{s}+(t+1) \beta_{\mathrm{SIC} 2} \\
& +\beta_{1} \mathrm{TI}_{s t}+\beta_{2} \mathrm{TI}_{s t}^{2}+\beta_{3} \mathrm{TI}_{s, t-2}+\beta_{4} \mathrm{TI}_{s, t-2}^{2}+\varepsilon_{i s, t+1} .
\end{aligned}
$$

The coefficients $\beta_{3}$ and $\beta_{4}$ capture the relation between innovation in year $t+1$ and the antitakeover law passage in year $t-2$. Thus, $\left(\beta_{3} \mathrm{TI}_{s, t-2}+\beta_{4} \mathrm{TI}_{s, t-2}^{2}\right)$ captures the effects on innovation 3 years after law passages and beyond. As a consequence, the term $\left(\beta_{1} \mathrm{TI}_{s t}+\beta_{2} \mathrm{TI}_{s t}^{2}\right)$ captures the effect in the first 2 years after the law change.

Columns 4-6 of Table 8 show the results of the above tests. We do not see any effect for $\mathrm{R} \& \mathrm{D} / \mathrm{Sales} 2$ years after the law passages; in fact, the inclusion of $\left(\beta_{3} \mathrm{TI}_{s, t-2}+\beta_{4} \mathrm{TI}_{s, t-2}^{2}\right)$ reduces the power of the main test and leads the effect $\left(\beta_{1} \mathrm{TI}_{s t}+\beta_{2} \mathrm{TI}_{s t}^{2}\right)$ to be insignificant as well. However, we find a robust effect for patents and citations 3 years after the law passages and beyond. We also notice that although $\beta_{1}$ and $\beta_{2}$ retain their expected signs, they are not statistically significant. Furthermore, the economic effects 3 years after the law passages are significantly higher than the effects immediately after the law passages, which suggests that the effect of antitakeover laws on innovation is largely felt in the long run. This evidence is consistent with the fact that innovation is a long-term activity involving long gestation periods.

\section{Tests Controlling for the Effects of Firm-Level Antitakeover Provisions}

Next, we conduct tests that control for the effects of firm-level antitakeover provisions using the GIM (2003) index. As we discuss in Section V.B, the inclusion of the GIM index as a control could potentially distort the coefficient estimates and standard errors of the exogenous variables. We, however, show the results of these tests as a robustness check.

Because the GIM (2003) index is available only from 1990 onward, the sample for these tests is restricted to 1990-1995. As seen in Table 1, there were many changes in antitakeover laws that occurred in 1990 and afterward; we exploit these changes in tests. Given the nonlinear effect of takeover pressure as predicted by our theory, we include both the level and the square of the GIM index. Table 9 reports results from these tests. We observe that even after controlling for the effects of firm-level antitakeover provisions, the predicted U-shaped relation between innovation and the antitakeover index continues to hold. 
TABLE 9

Effect of Takeover Pressure on Innovation After Controlling for the Effect of Firm-Level Antitakeover Provisions

Columns $1-3$ of Table 9 implement the following regression:

$$
y_{i s, t+1}=\beta_{i}+\beta_{t+1}+\beta_{1} \mathrm{Tl}_{s t}+\beta_{2} \mathrm{TI}_{s t}^{2}+\beta X_{i s t}+\varepsilon_{i s, t+1} .
$$

Columns 4-6 and 7-9 implement the following regressions, respectively:

$$
\begin{aligned}
y_{i s, t+1}= & \beta_{i}+\beta_{t+1}+\beta_{1} \mathrm{TI}_{s t}\left(\mathrm{TI}_{s t} \leq k\right)+\beta_{2} \mathrm{TI}_{s t}\left(\mathrm{TI}_{s t}>k\right)+\varepsilon_{i s, t+1}, \\
y_{i s, t+1}= & \beta_{i}+\beta_{t+1}+\beta_{1} \mathrm{TI}_{s t}\left(\mathrm{TI}_{s t} \leq k_{1}\right)+\beta_{2} \mathrm{TI}_{s t}\left(k_{1}<\mathrm{TI}_{s t}<k_{2}\right) \\
& +\beta_{3} \mathrm{TI}_{s t}\left(\mathrm{TI}_{s t} \geq k_{2}\right)+\varepsilon_{i s, t+1},
\end{aligned}
$$

where $k=2$ while $k_{1}=1$ and $k_{2}=4$. The variable $y_{i s, t+1}$ is a measure of innovation in year $t+1$ for firm $i$ incorporated in state $s$. The variable $\mathrm{TI}_{s t}$ equals the value of the antitakeover index in state $s$ at the end of year $t$. The variables $\beta_{i}$ and $\beta_{t+1}$ denote firm and year fixed effects, respectively. The knot point $k$ for the piecewise linear tests is set at $\mathrm{TI}_{\mathrm{st}}=2$ in the tests below. $X_{i s t}$ denotes the set of control variables. All regressions are estimated using ordinary least squares. The standard errors in parentheses are robust to both heteroskedasticity and autocorrelation and are clustered by state of incorporation, year. ${ }^{* \star *},{ }^{* \star}$, and ${ }^{*}$ indicate significance at the $1 \%, 5 \%$, and $10 \%$ levels, respectively.

Dependent Variable

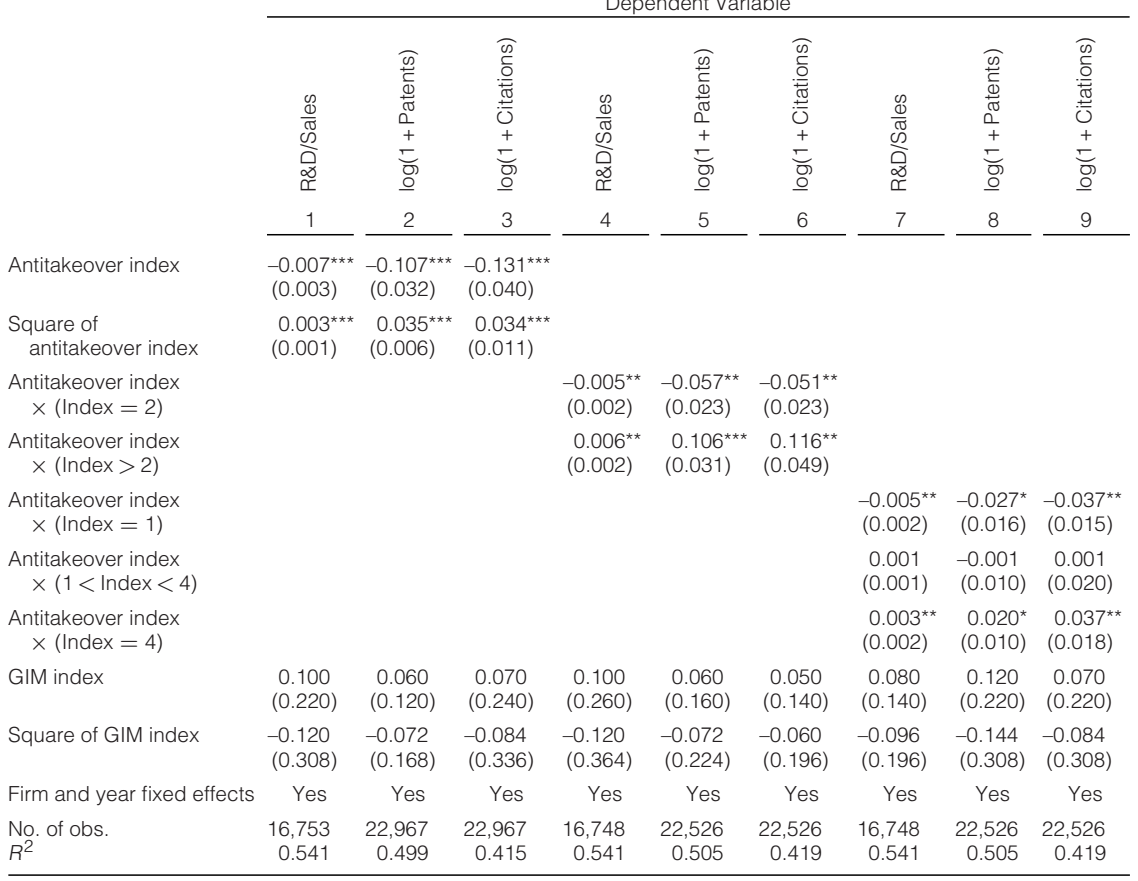

\section{Excluding Firms Incorporated in California, Delaware, and Massachusetts}

About half of our observations come from firms incorporated in Delaware, California, and Massachusetts. We examine whether these three states are driving our results by reestimating equation (23) after excluding observations for firms incorporated in these states. As seen in Table 10, the predicted U-shaped relation is robust even without the observations from these three states. Furthermore, the economic magnitude of the U-shaped relation is very similar to that obtained using the full sample, which indicates that these three states are not exclusively driving our results. 
TABLE 10

Effect of Takeover Pressure on Innovation Excluding Firms Incorporated in Delaware, California, and Massachusetts

Columns $1-5$ of Table 10 below implement the following regression:

$$
y_{i s, t+1}=\beta_{i}+\beta_{t+1}+\beta_{1} \mathrm{Tl}_{s t}+\beta_{2} \mathrm{TI}_{s t}^{2}+\beta X_{i s t}+\varepsilon_{i s, t+1} .
$$

The variable $y_{i s, t+1}$ is a measure of innovation in year $t+1$ for firm $i$ incorporated in state $s$. The variable $\mathrm{TI}_{s t}$ equals the value of the antitakeover index in state $s$ at the end of year $t$. The variables $\beta_{i}$ and $\beta_{t+1}$ denote firm and year fixed effects, respectively. $X_{\text {ist }}$ denotes the set of control variables. All regressions are estimated using ordinary least squares. The standard errors in parentheses are robust to both heteroskedasticity and autocorrelation and are clustered by state of incorporation, year. ${ }^{* *},{ }^{* *}$, and ${ }^{*}$ indicate significance at the $1 \%, 5 \%$, and $10 \%$ levels, respectively.

\begin{tabular}{|c|c|c|c|c|c|}
\hline & \multicolumn{5}{|c|}{ Dependent Variable } \\
\hline & R\&D/Sales & $\log$ (Patents) & $\log ($ Citations) & $\log ($ Patents/R\&D) & $\log ($ Citations/R\&D) \\
\hline & 1 & 2 & 3 & 4 & 5 \\
\hline Antitakeover index & $\begin{array}{l}-0.007^{\star \star \star} \\
(0.002)\end{array}$ & $\begin{array}{l}-0.089^{* * *} \\
(0.024)\end{array}$ & $\begin{array}{l}-0.144^{\star * *} \\
(0.045)\end{array}$ & $\begin{array}{l}-0.058^{\star \star \star} \\
(0.018)\end{array}$ & $\begin{array}{c}-0.084^{\star *} \\
(0.037)\end{array}$ \\
\hline Square of antitakeover index & $\begin{array}{l}0.002^{\star \star \star} \\
(0.000)\end{array}$ & $\begin{array}{l}0.027^{* * *} \\
(0.006)\end{array}$ & $\begin{array}{l}0.046^{\star \star \star} \\
(0.011)\end{array}$ & $\begin{array}{l}0.021^{\star \star \star} \\
(0.005)\end{array}$ & $\begin{array}{l}0.032^{\star \star \star} \\
(0.009)\end{array}$ \\
\hline $\log ($ Assets $)$ & $\begin{array}{l}-0.006^{\star \star \star} \\
(0.002)\end{array}$ & $\begin{array}{l}0.110^{\star \star \star} \\
(0.010)\end{array}$ & $\begin{array}{l}0.135^{\star \star \star} \\
(0.024)\end{array}$ & $\begin{array}{l}-0.081^{\star \star \star} \\
(0.017)\end{array}$ & $\begin{array}{l}-0.144^{\star \star \star} \\
(0.034)\end{array}$ \\
\hline Blockholder ownership & $\begin{array}{l}0.052^{\star \star \star} \\
(0.010)\end{array}$ & $\begin{array}{c}0.074 \\
(0.075)\end{array}$ & $\begin{array}{l}0.356^{* *} \\
(0.168)\end{array}$ & $\begin{array}{c}-0.073 \\
(0.090)\end{array}$ & $\begin{array}{c}0.061 \\
(0.178)\end{array}$ \\
\hline Industry Tobin's Q & $\begin{array}{c}0.000 \\
(0.000)\end{array}$ & $\begin{array}{c}-0.001 \\
(0.001)\end{array}$ & $\begin{array}{l}-0.001 \\
(0.001)\end{array}$ & $\begin{array}{c}0.001 \\
(0.002)\end{array}$ & $\begin{array}{c}0.001 \\
(0.003)\end{array}$ \\
\hline Competition & $\begin{array}{c}0.198 \\
(0.195)\end{array}$ & $\begin{array}{c}-0.423 \\
(2.879)\end{array}$ & $\begin{array}{c}-1.889 \\
(7.140)\end{array}$ & $\begin{array}{c}5.577^{*} \\
(3.175)\end{array}$ & $\begin{array}{c}8.500 \\
(5.301)\end{array}$ \\
\hline Square of competition & $\begin{array}{c}-0.142 \\
(0.173)\end{array}$ & $\begin{array}{c}0.196 \\
(2.595)\end{array}$ & $\begin{array}{c}1.076 \\
(6.449)\end{array}$ & $\begin{array}{c}-4.364 \\
(3.379)\end{array}$ & $\begin{array}{c}-5.922 \\
(5.540)\end{array}$ \\
\hline Industry value for innovation proxy & $\begin{array}{c}0.001^{*} \\
(0.001)\end{array}$ & $\begin{array}{l}0.233^{\star \star \star} \\
(0.023)\end{array}$ & $\begin{array}{l}0.288^{\star \star \star} \\
(0.026)\end{array}$ & $\begin{array}{l}0.094^{\star *} \\
(0.039)\end{array}$ & $\begin{array}{l}0.320^{\star \star \star} \\
(0.047)\end{array}$ \\
\hline Firm and year fixed effects & Yes & Yes & Yes & Yes & Yes \\
\hline $\begin{array}{l}\text { No. of obs. } \\
R^{2}\end{array}$ & $\begin{array}{r}18,096 \\
0.748\end{array}$ & $\begin{array}{r}19,755 \\
0.770\end{array}$ & $\begin{array}{r}19,755 \\
0.623\end{array}$ & $\begin{array}{r}14,095 \\
0.265\end{array}$ & $\begin{array}{r}14,095 \\
0.287\end{array}$ \\
\hline
\end{tabular}

\section{F. Discussion}

A firm can choose to reincorporate in another state if its original state of incorporation passes antitakeover laws. We believe that this possibility does not affect the inferences obtained from our tests for the following reasons.

First, antitakeover laws are not the sole determinant of incorporation decisions. For example, a state's corporate legal environment such as its bankruptcy laws, tax code, and promanagement tilt (in aspects other than antitakeover laws) may be important considerations that affect incorporation choices. Bebchuk and Cohen (2003) also find "home-state preference" to be a very important determinant of firms' incorporation decisions. They find that firms are more likely to be incorporated in states where they are located due to i) the higher costs of out-of-state incorporations, ii) the desire of firms to benefit from local favoritism, and iii) the influence of local lawyers. For several firms, these factors could

\footnotetext{
${ }^{8}$ One example is a state statute that gives management greater ability to eliminate dissident shareholders in a merger. Another example is a state statute that authorizes companies to limit or eliminate the liability of directors for all but disloyalty and other intentional bad acts.
} 
well outweigh the effects of antitakeover laws in determining their incorporation decisions.

Second, because the above essentially constitute state-level factors, they are captured by our empirical tests. The panel regressions have controlled for timeinvariant state-level factors and state-specific time trends that may affect such reincorporation choices. More important, our "division-level change-on-change" regressions control for the effects of any other state-level factors that accompanied the law passage and that may have affected firms' incorporation choices.

Third, in all cases, states passed laws that lowered takeover pressure. If the decision to reincorporate is motivated by entrenched managers, it is clearly not in the interests of such managers to reincorporate to avoid laws that lower takeover pressure.

Consistent with the preceding arguments, we find that only $0.58 \%$ of our sample comprises of firms that reincorporated following antitakeover law passages. Not surprisingly, our results are unaltered by excluding these observations.

\section{Conclusions}

We develop a parsimonious model to investigate how corporate governance mechanisms affect a firm's incentives to engage in innovation. Our model generates the novel prediction that there is a U-shaped relation between innovation and the takeover pressure the firm faces. Using ex ante and ex post measures of innovation, we show strong empirical support for the predicted U-shaped relation. By integrating contracting and a market for corporate control, our theory shows how the interplay between takeover premia and private benefits leads to a nonmonotonic relation between innovation and takeover pressure. From a policy standpoint, our results show that innovative activity is fostered by antitakeover laws that are either practically nonexistent or are strong enough to significantly deter takeovers.

Our study is relevant to the ongoing debate among lawyers and economists on whether antitakeover laws matter. Scholars often argue that antitakeover laws are irrelevant because firms adopt antitakeover provisions and/or choose compensation contracts for managers that negate the effects of laws. However, the very fact that firms respond to antitakeover laws itself means that these laws must matter. Moreover, when we derive the relation between innovation and the severity of antitakeover laws we incorporate the possibility that firms respond to changes in external takeover pressure through managerial contract choices. Our empirical findings show that antitakeover laws do, indeed, affect innovation.

Antitakeover laws potentially matter because they have the force of commitment. Firm-level antitakeover provisions can, and often are, renegotiated ex post. Furthermore, equilibria of games depend, in general, on off-equilibrium threats. Therefore, even if one were to hypothetically observe no effects of antitakeover laws on innovation (which is not true given our empirical findings), along the equilibrium path, the equilibrium itself could be supported by the existence of the laws. 


\section{Appendix A. Proofs of Propositions}

Proof of Proposition 1. (a) The expected payoff of the firm at date 1 if it is not taken over is $\mathrm{E}_{1}\left[P_{X}(2)\right]$, where $\mathrm{E}_{1}(\cdot)$ denotes the expectation with respect to date 1 information. Because the incumbent manager loses her control benefits if the firm is taken over, the total payoff to the firm's stakeholders (shareholders + manager) if the firm is taken over, and (hypothetically) no takeover premium is paid, is $\mathrm{E}_{1}\left[P_{X}(2)\right]-\alpha$. External antitakeover laws, however, ensure that for the takeover to be successful, the firm's stakeholders must receive a total expected payoff

$$
\mathrm{E}_{1}\left[P_{X}(2)\right]-\alpha+\eta, \quad \text { where } \eta>0 .
$$

It follows directly from expressions (1), (7), and (A-1) that the raider must generate a surplus for the firm. From the discussion in Sections 11.5.1 and 11.5.2 of Tirole (2006), free-riding by shareholders coupled with the fact that the raider obtains private control benefits ensures that it is optimal for the raider to make a tender offer that cedes the surplus he generates (less the control benefits he captures) to the firm. After the takeover, the firm's current stakeholders (shareholders + manager) therefore receive a total payoff at date 1 of

$$
P_{X}^{\mathrm{TAKEOVER}}=\mathrm{E}_{1}\left[P_{X}^{\mathrm{RAIDER}}(2)\right]-\alpha,
$$

where the expectation in equation (A-2) is with respect to the information available at date 1. It follows from expressions (A-1) and (A-2) that the takeover is successful if and only if

$$
\mathrm{E}_{1}\left[P_{X}^{\mathrm{RAIDER}}(2)\right] \geq \mathrm{E}_{1}\left[P_{X}(2)\right]+\eta
$$

In words, expression (A-3) states that the raider must increase the firm's expected payoff, conditional on the information available at date 1, by at least $\eta$. Using expressions (1), (7), (8), and (A-3), it follows that the raider succeeds in taking over the firm if and only if

$$
\begin{aligned}
\widehat{m}_{X}+\Theta\left(m_{X}-\widehat{m}_{X}\right) & \geq \widehat{m}_{X}+\eta, \\
\Leftrightarrow \quad \Theta\left(m_{X}-\widehat{m}_{X}\right) & \geq \eta .
\end{aligned}
$$

(b) The payoff to the firm upon a takeover follows directly from equation (A-2) and the fact that

$$
\mathrm{E}_{1}\left[P_{X}^{\mathrm{RAIDER}}(2)\right]=\widehat{m}_{X}+\Theta\left(m_{X}-\widehat{m}_{X}\right) .
$$

(c) From (a), the firm is taken over if and only if $\Theta\left(m_{X}-\widehat{m}_{X}\right) \geq \eta$. Using equation (4) to rewrite the mean posterior quality in the preceding inequality implies that the firm is taken over if and only if $s_{X} \geq \eta / \Theta$. Therefore, the probability of a takeover if the manager chooses project $X \in\{H, L\}$ is $\left[1-F_{X}(\eta / \Theta)\right]$, where $F_{X}(\cdot)$ is the cumulative distribution of the random variable $s_{X}$. Because $F_{H}(u) \leq F_{L}(u)$ by expression (6), the probability of a takeover is higher for the more innovative project.

Proof of Proposition 2. By equation (1), $\mathrm{E}\left(P_{X}(2)\right)=2 \mathrm{E}\left(\mu_{X}\right)=2 m_{X}$. By the arguments in the proof of Proposition 1, it is easy to show that in this benchmark environment too, a takeover successfully occurs if and only if condition (10) holds. By equation (7), consequently,

$$
\begin{aligned}
(\mathrm{A}-4) \mathrm{E}\left[1_{X}^{\mathrm{TAKEOVER}} \cdot\left(P_{X}^{\mathrm{RAIDER}}(2)-P_{X}(2)\right)\right] & =\Theta \mathrm{E}\left[1_{X}^{\mathrm{TAKEOVER}} \cdot\left(\nu_{X}^{\mathrm{RAIDER}}-\mu_{X}\right)\right] \\
& =\Theta \mathrm{E}\left[1_{X}^{\mathrm{TAKEOVER}} \cdot\left(m_{X}-\widehat{m}_{X}\right)\right] \\
& =\int_{\frac{\eta}{\Theta}}^{\infty} \Theta u f_{X}(u) d u,
\end{aligned}
$$


where the first equality above follows from expression (8) and the third follows from expressions (4) and (10). Therefore,

$$
\mathrm{E}\left(P_{X}(2)\right)+\mathrm{E}\left[1_{X}^{\mathrm{TAKEOVER}} \cdot\left(P_{X}^{\mathrm{RAIDER}}(2)-P_{X}(2)\right)\right]=2 m_{X}+\int_{\frac{\eta}{\Theta}}^{\infty} \Theta u f_{X}(u) d u .
$$

By expression (2), $m_{H}>m_{L}$. Next, using integration by parts:

$$
\int_{\frac{\eta}{\Theta}}^{\infty} \Theta u f_{X}(u) d u=\eta\left(1-F_{X}\left(\frac{\eta}{\Theta}\right)\right)+\int_{\frac{\eta}{\Theta}}^{\infty} \Theta\left[1-F_{X}(u)\right] d u .
$$

Because $\eta>0$, by expression (5), both the terms on the right-hand side above are larger for the more innovative project, $H$. Consequently,

$$
\int_{\frac{\eta}{\Theta}}^{\infty} \Theta u f_{H}(u) d u \geq \int_{\frac{\eta}{\Theta}}^{\infty} \Theta u f_{L}(u) d u
$$

and the manager chooses the more innovative project, $H$, in the benchmark scenario.

Proof of Proposition 3. As we note in the discussion preceding the statement of the proposition, the manager's reservation payoff $U>\alpha$ implies that we can ignore the limited liability constraint (17) as it does not bind. In the proof of Proposition 4, we show that this is indeed the case. We therefore proceed by ignoring the limited liability constraint. The participation constraint (16) must then be binding in the optimal contract so that:

$$
\mathrm{E}\left(w^{*}\left(Q_{X}\right)\right)=U-\mathrm{E}\left[\left(1_{X}^{\mathrm{NO} T A K E O V E R}\right) \cdot \alpha\right] .
$$

Substituting for $\mathrm{E}\left(w^{*}\left(Q_{X}\right)\right)$ in expression (15), we obtain

$$
\begin{aligned}
X^{*} & =\underset{X \in\{H, L\}}{\arg \max } \mathrm{E}\left[Q_{X}-w^{*}\left(Q_{X}\right)\right] \\
& =\underset{X \in\{H, L\}}{\arg \max } \mathrm{E}\left[Q_{X}\right]+\mathrm{E}\left[\left(1_{X}^{\text {NO TAKEOVER }}\right) \cdot \alpha\right]-U \\
& =\underset{X \in\{H, L\}}{\arg \max } \mathrm{E}\left[Q_{X}\right]+\mathrm{E}\left[\left(1_{X}^{\text {NO TAKEOVER }}\right) \cdot \alpha\right],
\end{aligned}
$$

where we have eliminated the constant $U$ from the objective function in the last line above because it does not affect the maximization problem. By expression (12), we obtain

$$
\begin{aligned}
& X^{*}=\underset{X \in\{H, L\}}{\arg \max } \mathrm{E}\left[\left(1_{X}^{\text {NO TAKEOVER }}\right)\left(P_{X}(2)-\alpha\right)\right]+\mathrm{E}\left[\left(1_{X}^{\text {TAKEOVER }}\right) P_{X}^{\text {TAKEOVER }}\right] \\
& +\mathrm{E}\left[\left(1_{X}^{\mathrm{NO} \text { TAKEOVER }}\right) \cdot \alpha\right] \\
& =\underset{X \in\{H, L\}}{\arg \max } \mathrm{E}\left[\left(1_{X}^{\text {NO TAKEOVER }}\right) P_{X}(2)\right]+\mathrm{E}\left[\left(1_{X}^{\text {TAKEOVER }}\right)\left(P_{X}^{\mathrm{RAIDER}}(2)-\alpha\right)\right] \\
& =\underset{X \in\{H, L\}}{\arg \max } \mathrm{E}\left(P_{X}(2)\right)+\mathrm{E}\left[1_{X}^{\text {TAKEOVER }} \cdot\left(P_{X}^{\mathrm{RAIDER}}(2)-P_{X}(2)\right)\right] \\
& -\mathrm{E}\left[1_{X}^{\text {TAKEOVER }} \cdot \alpha\right] \text {. }
\end{aligned}
$$

The second equality above follows from expression (11). The last equality follows by using the fact that $1_{X}^{\text {NO TAKEOVER }}=1-1_{X}^{\text {TAKEOVER }}$ and rearranging terms. Note that in deriving the 
optimal project choice $X^{*}$, we have ignored the incentive compatibility constraint (18). We show below in the proof of Proposition 4 that under the optimal contract, the constraint is indeed satisfied and the manager's optimal project choice solves expression (19).

Next, we note that

$$
\mathrm{E}\left(P_{X}(2)\right)=\mathrm{E}\left(2 \mu_{X}+r_{X 1}+r_{X 2}\right)=2 m_{X}
$$

because the random variables $r_{X 1}$ and $r_{X 2}$ have zero means. Now, observe that

$$
\mathrm{E}\left(1_{X}^{\text {TAKEOVER }} \cdot \alpha\right)=\alpha \mathrm{E}\left(1_{X}^{\text {TAKEOVER }}\right)=\alpha\left[1-F_{X}\left(\frac{\eta}{\Theta}\right)\right] .
$$

Next,

$$
\mathrm{E}\left[1_{X}^{\mathrm{TAKEOVER}} \cdot\left(P_{X}^{\mathrm{RAIDER}}(2)-P_{X}(2)\right)\right]=\int_{\frac{\eta}{\Theta}}^{\infty} \Theta u f_{X}(u) d u
$$

by expression (A-4). Equation (20) then follows from expressions (A-6), (A-7), and (A-8).

Proof of Proposition 4. The manager's objective function is:

$$
\begin{gathered}
\alpha+\mathrm{E}\left[w\left(Q_{X}\right)-1_{X}^{\text {TAKEOVER }} \alpha\right], \quad \text { or equivalently, } \\
\mathrm{E}\left[w\left(Q_{X}\right)-1_{X}^{\text {TAKEOVER }} \alpha\right] .
\end{gathered}
$$

The shareholder's objective function is $\mathrm{E}\left[Q_{X}-w\left(Q_{X}\right)\right]$. One way to make the project choice incentive compatible is to make the manager's objective function proportional to that of shareholders, that is,

$$
w\left(Q_{X}\right)-1_{X}^{\text {TAKEOVER }} \alpha=\gamma\left[Q_{X}-w\left(Q_{X}\right)\right],
$$

where $0<\gamma<1$ so that

$$
w\left(Q_{X}\right)=\frac{\gamma}{\gamma+1} Q_{X}+\frac{\alpha}{\gamma+1} 1_{X}^{\text {TAKEOVER }},
$$

where $\gamma$ is a parameter to be determined. Let $\lambda \equiv \gamma /(\gamma+1)$. Then

$$
w\left(Q_{X}\right)=\lambda Q_{X}+(1-\lambda) \alpha \cdot 1_{X}^{\text {TAKEOVER }} .
$$

The parameter $\gamma$ can then be solved from the manager's binding participation constraint, that is,

$$
\begin{aligned}
U & =\mathrm{E}\left[w\left(Q_{X}\right)+1_{X}^{\text {NO TAKEOVER }} \cdot \alpha\right] \\
& =\mathrm{E}\left[w\left(Q_{X}\right)+\left(1-1_{X}^{\text {TAKEOVER }}\right) \cdot \alpha\right] \\
& =\mathrm{E}\left[w\left(Q_{X}\right)-1_{X}^{\text {TAKEOVER }} \alpha\right]+\alpha \\
& =\gamma \mathrm{E}\left[Q_{X}-w\left(Q_{X}\right)\right]+\alpha
\end{aligned}
$$

where the last equality follows from equation (A-9). By expression (A-6),

$$
\begin{aligned}
U & =\gamma \mathrm{E}\left[Q_{X}-w\left(Q_{X}\right)\right]+\alpha \\
& =\gamma\left[2 m_{X}+\int_{\frac{\eta}{\Theta}}^{\infty} \Theta u f_{X}(u) d u-\alpha\left[1-F_{X}\left(\frac{\eta}{\Theta}\right)\right]-U\right]+\alpha .
\end{aligned}
$$


Therefore,

$$
U=\frac{\gamma}{\gamma+1}\left[2 m_{X}+\int_{\frac{\eta}{\Theta}}^{\infty} \Theta u f_{X}(u) d u-\alpha\left[1-F_{X}\left(\frac{\eta}{\Theta}\right)\right]\right]+\frac{\alpha}{\gamma+1} .
$$

Because $U>\alpha$, and $U$ must clearly be less than the total surplus,

$$
2 m_{X}+\int_{\frac{\eta}{\Theta}}^{\infty} \Theta u f_{X}(u) d u-\alpha\left[1-F_{X}(\eta / \Theta)\right],
$$

the preceding equation implies that $\gamma>0$ so that $\lambda=\gamma /(\gamma+1)<1$. Now observe that

$$
\begin{aligned}
w\left(Q_{X}\right)+\left(1_{X}^{\text {NO TAKEOVER }}\right) \cdot \alpha & =\lambda Q_{X}+(1-\lambda) \alpha \cdot 1_{X}^{\text {TAKEOVER }}+\left(1_{X}^{\text {NO TAKEOVER }}\right) \cdot \alpha \\
& =\lambda Q_{X}+\alpha-\lambda \alpha 1_{X}^{\text {TAKEOVER }}>0 .
\end{aligned}
$$

Hence, the limited liability constraint is, indeed, binding as we had assumed in the proof of Proposition 3 and in deriving the optimal contract. In other words, the contract derived above implements the optimal project choice described by Proposition 3 and satisfies limited liability for the manager.

Proof of Proposition 5. Define the expected excess payoff from the more innovative project over the less innovative project by the function $G(\eta, \alpha)$, where

$$
G(\eta, \alpha) \equiv 2 m_{H}-2 m_{L}+H(\eta, \alpha),
$$

and

$$
H(\eta, \alpha) \equiv \int_{\frac{\eta}{\Theta}}^{\infty} \Theta u\left(f_{H}(u)-f_{L}(u)\right) d u+\alpha\left[F_{H}\left(\frac{\eta}{\Theta}\right)-F_{L}\left(\frac{\eta}{\Theta}\right)\right]
$$

Note that as $\eta \rightarrow \infty, \lim H(\infty, \alpha)=0$ so that the expected excess payoff $G(\infty, \alpha)=$ $2 m_{H}-2 m_{L}>0$. As $\eta \rightarrow 0$,

$$
H(0, \alpha)=\int_{0}^{\infty} \Theta u\left(f_{H}(u)-f_{L}(u)\right) d u+\alpha\left[F_{H}(0)-F_{L}(0)\right] .
$$

By continuity of the distribution functions, $F_{H}(\cdot)$ and $F_{L}(\cdot)$, conditions (5) together imply that $F_{H}(0)=F_{L}(0)$. It follows from the arguments in the proof of Proposition 2 that

$$
\int_{0}^{\infty} \Theta u\left(f_{H}(u)-f_{L}(u)\right) d u>0 .
$$

Consequently, $G(0, \alpha)=2 m_{H}-2 m_{L}+H(0, \alpha)>0$. Thus, the manager chooses the more innovative project for relatively low and relatively high levels of takeover pressure.

We now show that if the private control benefits parameter is sufficiently high, lower innovation may be optimal for moderate levels of takeover pressure. Differentiating $G(\eta, \alpha)$ with respect to $\eta$ yields:

$$
\frac{\partial G(\eta, \alpha)}{\partial \eta}=\left[\frac{\alpha}{\Theta}-\frac{\eta}{\Theta}\right] f_{H}\left(\frac{\eta}{\Theta}\right)-\left[\frac{\alpha}{\Theta}-\frac{\eta}{\Theta}\right] f_{L}\left(\frac{\eta}{\Theta}\right) .
$$

We note that $\partial G(\eta, \alpha) / \partial \eta=0$ when either $\alpha=\eta$ or at a value $\widehat{\eta}$ that satisfies

$$
\frac{f_{H}\left(\frac{\widehat{\eta}}{\Theta}\right)}{f_{L}\left(\frac{\widehat{\eta}}{\Theta}\right)}=1 \text {. }
$$


By expression (5), there exists $u>0$ such that $f_{H}(u)>f_{L}(u)$. Furthermore,

$$
F_{H}(x)-F_{H}(-x)<F_{L}(x)-F_{L}(-x) \text { for } x>0 .
$$

Dividing both sides by $2 x$ and taking the limit as $x \longrightarrow 0$, we see that $f_{H}(0)<f_{L}(0)$. Condition (6) then implies that equation (A-14) has a unique solution at $\eta=\widehat{\eta}$. Consequently, $f_{H}(\eta / \Theta)<f_{L}(\eta / \Theta)$ for $\eta \in[0, \widehat{\eta})$ and $f_{H}(\eta / \Theta)>f_{L}(\eta / \Theta)$ for $\eta \in(\widehat{\eta},+\infty)$ so that

$$
\frac{\partial G(\eta, \alpha)}{\partial \eta} \begin{cases}<0, & \text { if } \eta \in[0, \min (\widehat{\eta}, \alpha)) ; \\ =0, & \text { if } \eta=\widehat{\eta} \text { or } \alpha ; \\ >0, & \text { if } \eta \in(\min (\widehat{\eta}, \alpha), \max (\widehat{\eta}, \alpha)) \\ <0, & \text { if } \eta>\max (\widehat{\eta}, \alpha) .\end{cases}
$$

From the behavior of $\partial G(\eta, \alpha) / \partial \eta$ described above, it follows that:

(i) $\min (\widehat{\eta}, \alpha)$ is a local minimum for $G(\eta, \alpha)$;

(ii) $G(\eta, \alpha)$ is weakly decreasing in $\eta$ if $\alpha=\widehat{\eta}$.

We now observe that if $\alpha \leq \widehat{\eta}$, then $G(\eta, \alpha)>0 \forall \eta \in[0,+\infty)$. To see this, note that because $G(\infty, \alpha)=0$, condition (ii) implies that $G(\eta, \alpha) \geq 0$ if $\alpha=\widehat{\eta}$. The observation then follows because $\partial G(\eta, \alpha) / \partial \alpha=\left(F_{H}(\eta / \Theta)-F_{L}(\eta / \Theta)\right)<0$.

Given the preceding observation, the necessary and sufficient condition for the inter$\operatorname{val}\left(\eta_{\min }, \eta_{\max }\right)$ to exist is:

$$
G(\widehat{\eta}, \alpha)<0
$$

where $G\left(\eta_{\min }, \alpha\right)=G\left(\eta_{\max }, \alpha\right)=0$ and $\hat{\eta}$ solves $f_{H}(\eta / \Theta)=f_{L}(\eta / \Theta)$. Using equations (A-11) and (A-12), the necessary and sufficient condition described in inequality (A-15) becomes:

$$
\alpha>\alpha_{\min } \equiv \frac{2\left(m_{H}-m_{L}\right)+\int_{\frac{\hat{\eta}}{\Theta}}^{\infty} \Theta u\left(f_{H}(u)-f_{L}(u)\right) d u}{F_{L}\left(\frac{\widehat{\eta}}{\Theta}\right)-F_{H}\left(\frac{\widehat{\eta}}{\Theta}\right)}>0
$$

Proof of Proposition 6. Let $\bar{\eta}$ satisfy $G(\bar{\eta}, \alpha)=0$, so that $\eta_{\min }, \eta_{\max }$ are the thresholds defined above that satisfy $G\left(\eta_{\min }, \alpha\right)=G\left(\eta_{\max }, \alpha\right)=0$. Using the Implicit Function Theorem:

$$
\frac{d \bar{\eta}}{d \alpha}=\left.\frac{-\frac{\partial G}{\partial \alpha}}{\frac{\partial G}{\partial \eta}}\right|_{\eta=\bar{\eta}}=\left.\frac{F_{L}\left(\frac{\eta}{\Theta}\right)-F_{H}\left(\frac{\eta}{\Theta}\right)}{\frac{\partial H(\eta, \alpha)}{\partial \eta}}\right|_{\eta=\bar{\eta}} .
$$

The numerator of expression (A-17) is positive. From the proof of Proposition 5, the denominator of expression (A-17) is negative for $\bar{\eta}=\eta_{\min }$ and positive for $\bar{\eta}=\eta_{\max }$. This completes the proof.

\section{Appendix B. General Model}

In this appendix, we extend the basic model in two ways. First, we allow for both disciplinary and synergistic takeovers. Second, we allow for the raider's quality to be drawn from a different distribution than that of the original project. trol is

As in the basic model, the project's terminal payoff at date 2 under the raider's con-

$$
P_{X}^{\mathrm{RAIDER}}(2)=P_{X}(1)+\mu_{X}^{\mathrm{RAIDER}}+r_{X 3}
$$


We now define a potential raider by its "complementarity/substitutability" parameter $\chi \in$ $[-\Theta, \Theta]$ where $\Theta>0$. The true expected return $\mu_{X}^{\mathrm{RAIDER}}(\chi)$ generated by a raider with parameter $\chi$ is:

$$
\begin{aligned}
\mu_{X}^{\mathrm{RAIDER}}(\chi) & =(1-\chi) \mu_{X}+\chi \nu_{X}^{\mathrm{RAIDER}} \\
& =\mu_{X}+\chi\left(\nu_{X}^{\mathrm{RAIDER}}-\mu_{X}\right)
\end{aligned}
$$

The true expected return generated by the raider is therefore a linear combination of the project's intrinsic quality and the raider's intrinsic quality $\nu_{X}^{\text {RAIDER }}$. We generalize the basic model to allow for $\nu_{X}^{\text {RAIDER }}$ to be drawn from a different distribution, $M_{X}^{\text {RAIDER }}$, than that of the original project with the mean intrinsic quality, $m_{X}^{\text {RAIDER }}$, of the raider also being different. In particular, $m_{X}^{\text {RAIDER }}$ could be greater than or less than $m_{X}$. To simplify the notation and analysis, we assume that

$$
m_{H}^{\text {RAIDER }}-m_{H}=m_{L}^{\text {RAIDER }}-m_{L}=\rho,
$$

which implies that the mean excess expected returns generated by the raider are the same for the more and less innovative projects. Note that if $m_{X}^{\text {RAIDER }}=m_{X}$, we recover the model in the main body of the article.

Second, we assume that the takeover pressure $\eta$ is such that

$$
|\rho| \leq \frac{\eta}{\Theta}, \quad \text { for } X \in\{H, L\}
$$

If the above condition were violated, it would be optimal for a raider to take over the firm at date 0 itself. Given that we are interested in potential takeovers at date 1, we are effectively examining the more interesting scenario where firms are not takeover targets at date 0 .

In Section III.D, we had set $\chi=\Theta$, which implies that the raider adds value when the intrinsic quality of its project is greater than that of the incumbent project. Consequently, only underperforming firms are taken over; that is, takeovers are disciplinary in nature. This could be viewed as a scenario in which the raider's project "substitutes" the firm's project if it is acquired, which is consistent with the general perspective on disciplinary takeovers (Auerbach (1988)). In contrast, because the parameter $\chi$ can also take negative values, it follows directly from expression (B-2) that a raider with a negative value of $\chi$ adds value if and only if $\mu_{X}>\nu_{X}^{\text {RAIDER }}$. We could view this scenario as one in which the raider possesses assets that are complementary to those of the incumbent firm so that the payoff of a high-quality project is further enhanced through synergies with the acquiring firm; that is, the raider's project "complements" the firm's project. This is consistent with the general perspective on synergistic takeovers that exploit complementarities between a firm and an acquirer (Auerbach (1988)). A raider with a positive (negative) value of $\chi$ could be viewed as a "disciplinary" ("synergistic") raider who adds value when the project's quality is low (high) relative to the pool of potential projects. The parameter $\chi$, therefore, captures the degree of substitutability between the firm's and raider's projects if it is positive and the degree of complementarity between the firm's and raider's projects if it is negative.

As in the main model, the severity of antitakeover laws determines the bargaining power of the firm vis-à-vis the raider, which manifests in the minimum takeover premium the raider must offer the firm. Even though antitakeover laws are primarily relevant for hostile takeovers, the targets in hostile takeovers could also be out-performing firms, that is, hostile takeovers could comprise of disciplinary as well as synergistic takeovers. Further, antitakeover laws represent important signals of the general level of takeover pressure in the state that could influence the bargaining power of targets of all types of takeovers.

The following proposition generalizes Proposition 1 to accommodate both disciplinary and synergistic takeovers. Furthermore, as is intuitively obvious, from the pool of potential raiders described by the set of possible synergy parameters $[-\Theta, \Theta]$, the raider 
that succeeds in taking over the firm is the one that generates the maximum additional value.

Proposition 7. Likelihood of Takeover and Takeover Payoff. (a) The firm is successfully acquired if and only if

$$
\Theta\left|m_{X}^{\mathrm{RAIDER}}-\widehat{m}_{X}\right| \geq \eta
$$

where $\widehat{m}_{X}$ is the mean posterior project quality at date 1 (see equation (4)).

(b) If $\widehat{m}_{X}>m_{X}^{\text {RAIDER }}$, and condition (B-5) holds, the raider with synergy $-\Theta$ takes over the firm. If $\widehat{m}_{X}<m_{X}^{\text {RAIDER }}$, and condition (B-5) holds, the raider with synergy $\Theta$ takes over the firm.

(c) The total payoff the firm receives from the raider is

$$
P_{X}^{\mathrm{TAKEOVER}}=\mathrm{E}_{1}\left[P_{X}^{\mathrm{RAIDER}}(2)-\alpha\right]=\widehat{m}_{X}+\Theta\left|\widehat{m}_{X}-m_{X}^{\mathrm{RAIDER}}\right|-\alpha .
$$

(d) The likelihood of a takeover is higher for the more innovative project.

Proof. The proofs of conditions (a), (b), and (c) follow using very similar arguments to those used to prove Proposition 1. For condition (d), note that the probability of a takeover is given by

$$
\begin{aligned}
\operatorname{Pr}\left[\left|m_{X}^{\mathrm{RAIDER}}-\widehat{m}_{X}\right| \geq \frac{\eta}{\Theta}\right] & =\operatorname{Pr}\left[\left|m_{X}^{\mathrm{RAIDER}}-m_{X}+m_{X}-\widehat{m}_{X}\right| \geq \frac{\eta}{\Theta}\right] \\
& =\operatorname{Pr}\left[m_{X}-\widehat{m}_{X} \geq \frac{\eta}{\Theta}-\rho\right]+\operatorname{Pr}\left[\widehat{m}_{X}-m_{X} \leq-\frac{\eta}{\Theta}-\rho\right] \\
& =1-F_{X}\left[\frac{\eta}{\Theta}-\rho\right]+F_{X}\left[-\frac{\eta}{\Theta}-\rho\right] .
\end{aligned}
$$

By expressions (5) and (B-4), the last expression above is higher for the more innovative project.

Condition (a) implies that the takeover is successful if and only if the expected synergies generated by the raider are sufficiently high to compensate for the takeover premium that it must pay the firm. Conditions (a) and (b) together imply that the firm is taken over if the posterior mean assessment of project quality is either sufficiently high or sufficiently low, that is, if it receives either a sufficiently positive or a sufficiently negative intermediate signal at date 1 . The prediction that significantly over- or underperforming firms are taken over is consistent with evidence on the takeover market. In reality, takeovers can be synergistic in the sense that "good" firms are taken over or disciplinary in which "bad" firms are taken over. Our analysis accommodates both types of takeovers. Condition (d) implies that the likelihood of a takeover (synergistic or disciplinary) is higher for the more innovative project. Because the payoff distribution of the more innovative project has fatter tails, it is more likely to generate significantly positive or significantly negative signals; that is, higher innovation is more likely to succeed as well as fail. The following proposition generalizes Proposition 3 (its proof proceeds along very similar lines).

Proposition 8. Optimal Project Choice. The manager's optimal project choice solves

$$
\begin{aligned}
\max _{X \in\{H, L\}} \underbrace{2 m_{X}}_{\text {unconditional expected payoffs }} & +\underbrace{\int_{\frac{\eta}{\Theta}-\rho}^{\infty} \Theta u f_{X}(u) d u-\int_{-\infty}^{-\frac{\eta}{\Theta}-\rho} \Theta u f_{X}(u) d u}_{\text {expected takeover premium }} . \\
- & \underbrace{\alpha\left[1-F_{X}\left(\frac{\eta}{\Theta}-\rho\right)+F_{X}\left(-\frac{\eta}{\Theta}-\rho\right)\right]}_{\text {expected control benefits loss }} .
\end{aligned}
$$

We now generalize Proposition 5 to this setting. 
Proposition 9. Effect of Takeover Pressure on Innovation. There exist $\eta_{\min }, \eta_{\max }$ such that the manager chooses the more innovative project for $\eta \notin\left[\eta_{\min }, \eta_{\max }\right]$.

Proof. As in the proof of Proposition 5, define the expected excess payoff from the more innovative project over the less innovative project by the function $G(\eta, \alpha)$, where

$$
G(\eta, \alpha) \equiv 2 m_{H}-2 m_{L}+H(\eta, \alpha),
$$

and

$$
\begin{aligned}
H(\eta, \alpha) \equiv & \int_{\frac{\eta}{\Theta}-\rho}^{\infty} \Theta u\left(f_{H}(u)-f_{L}(u)\right) d u-\int_{-\infty}^{-\frac{\eta}{\Theta}-\rho} \Theta u\left(f_{H}(u)-f_{L}(u)\right) d u \\
& +\alpha\left[F_{H}\left(\frac{\eta}{\Theta}-\rho\right)-F_{L}\left(\frac{\eta}{\Theta}-\rho\right)\right] \\
& +\alpha\left[F_{L}\left(-\frac{\eta}{\Theta}-\rho\right)-F_{H}\left(-\frac{\eta}{\Theta}-\rho\right)\right] .
\end{aligned}
$$

Note that as $\eta \rightarrow \infty, \lim H(\infty, \alpha)=0$ so that the expected excess payoff $G(\infty, \alpha)=$ $2 m_{H}-2 m_{L}>0$. Given expression (B-4), the lower bound for the takeover pressure parameter is $\eta_{\text {low }}=|\rho| \Theta$. Using condition (5), we can show that

$$
T=\int_{\frac{\eta_{\text {low }}}{\Theta}-\rho}^{\infty} \Theta u\left(f_{H}(u)-f_{L}(u)\right) d u-\int_{-\infty}^{-\frac{\eta_{\text {low }}}{\Theta}-\rho} \Theta u\left(f_{H}(u)-f_{L}(u)\right) d u>0 .
$$

Since $\eta_{\text {low }}=|\rho| \Theta$

$$
\begin{aligned}
S= & \alpha\left[F_{H}\left(\frac{\eta_{\text {low }}}{\Theta}-\rho\right)-F_{L}\left(\frac{\eta_{\text {low }}}{\Theta}-\rho\right)\right] \\
& +\alpha\left[F_{L}\left(-\frac{\eta_{\text {low }}}{\Theta}-\rho\right)-F_{H}\left(-\frac{\eta_{\text {low }}}{\Theta}-\rho\right)\right] \\
= & \alpha\left[F_{H}(|\rho|-\rho)-F_{L}(|\rho|-\rho)\right]+\alpha\left[F_{L}(-|\rho|-\rho)-F_{H}(-|\rho|-\rho)\right] \\
= & \alpha\left[F_{L}(-2 \rho)-F_{H}(-2 \rho)\right] \text { if } \rho>0 \\
= & \alpha\left[F_{H}(-2 \rho)-F_{L}(-2 \rho)\right] \text { if } \rho<0 .
\end{aligned}
$$

In both cases, $S>0$. However, if we assume that

$$
2 m_{H}-2 m_{L}+T>-S,
$$

then $G\left(\eta_{\text {low }}, \alpha\right)>0$ so that choosing the more innovative project is optimal for $\eta=\eta_{\text {low }}$. Note that condition (B-8) always holds if $\rho=0$ and, more generally, if $|\rho|$ is less than a threshold.

Differentiating $G(\eta, \alpha)$ with respect to $\eta$

$$
\begin{aligned}
\frac{\partial G(\eta, \alpha)}{\partial \eta}= & {\left[\frac{\alpha-\eta}{\Theta}+\rho\right]\left[f_{H}\left(\frac{\eta}{\Theta}-\rho\right)+f_{H}\left(-\frac{\eta}{\Theta}-\rho\right)\right] } \\
& -\left[\frac{\alpha-\eta}{\Theta}-\rho\right]\left[f_{L}\left(-\frac{\eta}{\Theta}-\rho\right)+f_{L}\left(-\frac{\eta}{\Theta}-\rho\right)\right] .
\end{aligned}
$$

If $\rho=0$, then $\partial G(\eta, \alpha) / \partial \eta=0$ for $\eta=\alpha$ and for $\eta=\widehat{\eta}$, where $\left[f_{H}(\widehat{\eta} / \Theta)+f_{H}(-\widehat{\eta} / \Theta)\right] /$ $\left[f_{L}(\widehat{\eta} / \Theta)+f_{L}(-\widehat{\eta} / \Theta)\right]=1$. If we extend (6) to assume that $\left[f_{H}(x)+f_{H}(-x)\right] /$ $\left[f_{L}(x)+f_{L}(-x)\right]$ is strictly increasing for $x>0$, then $\widehat{\eta}$ is unique. A straightforward extension of the proof of Proposition 5 then shows that there exist $\eta_{\min }, \eta_{\max }$ such that the manager chooses the less innovative project for $\eta \in\left(\eta_{\min }, \eta_{\max }\right)$ and the more innovative project for $\eta \notin\left(\eta_{\min }, \eta_{\max }\right)$. If $\rho \neq 0$, the equation $\partial G(\eta, \alpha) / \partial \eta=0$ could have multiple roots in $[0, \infty)$. Nevertheless, if condition (B-8) holds, there exist thresholds 
$\eta_{\min }$ and $\eta_{\max }$ such that it is optimal to choose the more innovative project for $\eta \notin\left[\eta_{\min }, \eta_{\max }\right]$. For $\eta \in\left(\eta_{\min }, \eta_{\max }\right)$, it could, in general, be optimal to choose either the more or less innovative project.

Proposition 9 shows that, in general, it is optimal to choose the more innovative project for high and low levels of takeover pressure. For intermediate levels of takeover pressure, either high or low innovation may be optimal. It is still the case, however, that, on average, it is optimal to choose greater innovation for high and low levels of takeover pressure and lower innovation for intermediate levels so that our testable prediction of a U-shaped relation remains unaltered.

\section{References}

Acharya, V.; R. Baghai; and K. V. Subramanian. "Wrongful Discharge Laws and Innovation." Review of Financial Studies, 27 (2014), 301-346.

Acharya, V., and K. V. Subramanian. "Bankruptcy Codes and Innovation." Review of Financial Studies, 12 (2009), 4949-4988.

Aghion, P.; N. Bloom; R. Blundell; R. Griffith; and P. Howitt. "Competition and Innovation: An Inverted-U Relationship.” Quarterly Journal of Economics, 120 (2005), 701-728.

Aghion, P., and P. Howitt. "Appropriate Growth Policy: A Unifying Framework." Journal of the European Economic Association, 4 (2006), 269-314.

Aghion, P.; J. Van Reenen; and L. Zingales. "Innovation and Institutional Ownership." American Economic Review, 103 (2013), 277-304.

Ai, C., and E. C. Norton. "Interaction Terms in Logit and Probit Models." Economics Letters, 80 (2003), 123-129.

Angrist, J., and J. Pischke. Mostly Harmless Econometrics: An Empiricist's Companion. Princeton, NJ: Princeton University Press (2009), 221-248.

Atanassov, J. "Do Hostile Takeovers Stifle Innovation? Evidence from Antitakeover Legislation and Corporate Patenting." Journal of Finance, 68 (2013), 1097-1131.

Auerbach. A. U., ed. Corporate Takeovers: Causes and Consequences. Chicago, IL: University of Chicago Press (1988).

Bebchuk, L., and A. Cohen. "Firms' Decisions Where to Incorporate." Journal of Law and Economics, 46 (2003), 383-425.

Bebchuk, L., and A. Cohen. "The Costs of Entrenched Boards." Journal of Financial Economics, 78 (2005), 409-433.

Bebchuk, L., and C. Jolls. "Managerial Value Diversion and Shareholder Wealth." Journal of Law, Economics, and Organization, 15 (1999), 487-502.

Bertrand, M., and S. Mullainathan. "Enjoying the Quiet Life? Corporate Governance and Managerial Preferences." Journal of Political Economy, 111 (2003), 1043-1075.

Besley, T., and R. Burgess. "Can Labor Regulation Hinder Economic Performance? Evidence from India." Quarterly Journal of Economics, 119 (2004), 91-134.

Chava, S.; A. Oettl; A. Subramanian; and K. V. Subramanian. "Banking Deregulation and Innovation." Journal of Financial Economics, 109 (2013), 759-774.

Chemmanur, T. J., and X. Tian. "Do Anti-Takeover Provisions Spur Corporate Innovation?" Working Paper, Boston University and Indiana University (2012).

Comment, R., and G. W. Schwert. "Poison or Placebo? Evidence on the Deterrence and Wealth Effects of Modern Anti-Takeover Measures." Journal of Financial Economics, 39 (1995), 3-43.

Desyllas, P., and A. Hughes. "The Revealed Preferences of High Technology Acquirers: An Analysis of the Innovation Characteristics of Their Targets." Cambridge Journal of Economics, 33 (2009), 1089-1111.

Field, L. C., and J. M. Karpoff. “Takeover Defenses of IPO Firms.” Journal of Finance, 57 (2002), 1857-1889.

Francis, J., and A. Smith. "Agency Costs and Innovation: Some Empirical Evidence." Journal of Accounting and Economics, 19 (1995), 383-409.

Giroud, X., and H. Mueller. "Corporate Governance, Product Market Competition, and Equity Prices." Journal of Finance, 66 (2011), 563-600.

Gompers, P.; J. Ishii; and A. Metrick. "Corporate Governance and Equity Prices.” Quarterly Journal of Economics, 118 (2003), 107-155.

Griliches, Z.; A. Pakes, and B. Hall. "The Value of Patents as Indicators of Inventive Activity." In Economic Policy and Technological Performance, P. Dasgupta and P. Stoneman, eds. Cambridge, United Kingdom: Cambridge University Press (1987). 
Hall, B.; A. Jaffe; and M. Trajtenberg. "The NBER Patent Citations Data File: Lessons, Insights, and Methodological Tools.” Working Paper 8498, National Bureau of Economic Research (2001).

Imbens, G., and J. M. Wooldridge. "Recent Developments in the Econometrics of Program Evaluation." Journal of Economic Literature 47 (2009), 5-86.

Jensen, M. "Takeovers: Causes and Consequences." Journal of Economic Perspectives, 2 (1988), 21-48.

Karpoff, J., and P. Malatesta. "The Wealth Effects of Second Generation State Takeover Legislation.” Journal of Financial Economics, 25 (1989), 291-322.

Kortum, S., and J. Lerner. "What Is Behind the Recent Surge in Patenting?" Research Policy, 28 (1999), 1-22.

La Porta, R.; F. Lopez-de-Silanes; A. Shleifer; and R. W. Vishny. "Investor Protection and Corporate Governance." Journal of Financial Economics, 58 (2000), 3-27.

Lel, U., and D. P. Miller. "International Cross-Listing, Firm Performance, and Top Management Turnover: A Test of the Bonding Hypothesis.” Journal of Finance, 63 (2008), 1897-1937.

Manso, G. "Motivating Innovation.” Journal of Finance, 66 (2011), 1823-1860.

Meulbroek, L. K.; M. L. Mitchell; J. H. Mulherin; J. M. Netter; and A. B. Poulsen. "Shark Repellents and Managerial Myopia: An Empirical Test.” Journal of Political Economy, 98 (1990), 1108-1117.

Scharfstein, D. "The Disciplinary Role of Takeovers." Review of Economic Studies, 55 (1988), 195-199.

Shleifer, A., and L. H. Summers. "Breach of Trust in Hostile Takeovers." In Corporate Takeovers: Causes and Consequences, A. J. Auerbach, ed. Chicago: University of Chicago Press (1988), 33-56.

Stein, J. C. "Takeover Threats and Managerial Myopia." Journal of Political Economy, 96 (1988), 61-80.

Tirole, J. Theory of Corporate Finance. Princeton, NJ: Princeton University Press (2006).

Wooldridge, J. Econometric Analysis of Cross Section and Panel Data, 1st ed. Cambridge, MA: MIT Press (2002). 